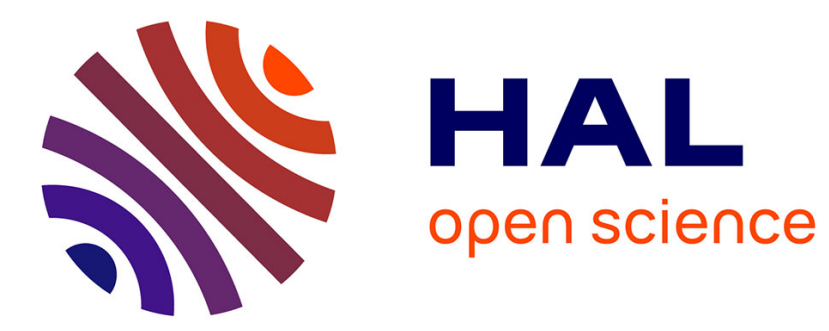

\title{
Labour market institutions and the personal distribution of income in the OECD
}

Daniele Checchi, Cecilia Garcìa-Peñalosa

\section{To cite this version:}

Daniele Checchi, Cecilia Garcìa-Peñalosa. Labour market institutions and the personal distribution of income in the OECD. 2008. halshs-00341005

\section{HAL Id: halshs-00341005 \\ https://shs.hal.science/halshs-00341005}

Preprint submitted on 24 Nov 2008

HAL is a multi-disciplinary open access archive for the deposit and dissemination of scientific research documents, whether they are published or not. The documents may come from teaching and research institutions in France or abroad, or from public or private research centers.
L'archive ouverte pluridisciplinaire HAL, est destinée au dépôt et à la diffusion de documents scientifiques de niveau recherche, publiés ou non, émanant des établissements d'enseignement et de recherche français ou étrangers, des laboratoires publics ou privés. 


\section{LABOUR MARKET INSTITUTIONS AND THE PERSONAL DISTRIBUTION OF INCOME IN THE OECD}

\author{
Daniele Checchi
}

Cecilia García-Peñalosa

October 2008 


\section{LABOUR MARKET INSTITUTIONS AND THE PERSONAL DISTRIBUTION OF INCOME IN THE OECD*}

\author{
Daniele Checchi a \\ University of Milan and IZA
}

and

\author{
Cecilia García-Peñalosa ${ }^{b}$ \\ CNRS and GREQAM
}

October 2008

Abstract: A large literature has studied the impact of labour market institutions on wage inequality, but their effect on income inequality has received little attention. In this paper we argue that personal income inequality is a function of the wage differential, the labour share, and the unemployment rate. Labour market institutions then affect income inequality through these three channels and their overall effect is theoretically ambiguous. We use a panel of OECD countries for the period 1960-2000 to examine these effects. We find that greater unionization and a higher degree of wage bargaining coordination have opposite effects on inequality, implying conflicting effects of greater union presence on the distribution of income.

JEL classification numbers: D31 (Personal Income, Wealth, and their Distributions) - D33 (Factor Income Distribution)

Key words: income inequality, labour share, trade unions.

\footnotetext{
* We thank the participants to the seminars at IZA-Bonn, Universidad Autonoma de Barcelona, IGIER Bocconi, Florence, Milan University, Freie Universitat, the Institute of Industrial Economics Stockolm, the Hebrew University of Jerusalem, and at the SASE and ECINEQ conferences. We especially thank Andrea Bassanini, Andrea Brandolini, Pierre-Philippe Combes, Andrea Cornia, Peter Gottschalk and Claudio Lucifora for helpful discussions, and two anonymous referees. Daniele Checchi gratefully acknowledges the financing of the Italian Ministry of Education (Cofin n. 2003137385); Cecilia García-Peñalosa’s research was partly supported by the Institut d'Economie Publique (IDEP) in Marseille.

a University of Milan, Department of Economics, via Conservatorio 7, 20124 Milan, Italy. Email: daniele.checchi@unimi.it

b GREQAM, Centre de la Vieille Charité, 2 rue de la Charité, 13002 Marseille, France. Email: cecilia.garciapenalosa@univmed.fr
} 


\section{Introduction}

The past two decades have witnessed a revival of interest in the determinants of inequality, and extensive empirical work has tried to assess its evolution and the possible causes of changes over time and across countries. The large majority of this work has focussed on a single measure of inequality, concentrating on either wage inequality, income inequality, or the labour share (see, for example, Katz and Murphy, 1992; Atkinson, 1997; and Blanchard, 1997). Yet all three forms of inequality are closely related, as they are likely to have similar causes and potentially affect each other. This paper provides a unified framework in which to examine the determinants of wage dispersion, the labour share, and the personal distribution of income. We argue that labour market institutions are the central element linking these three variables, and use data for OECD countries to evaluate the impact of institutions on these three forms of inequality.

We start by presenting a unified theoretical framework, which considers how labour market institutions affect the three essential labour market outcomes - the wage differential between skilled and unskilled workers, the labour share, and the unemployment rate - and, through them, personal income inequality. Our analysis involves two steps. First, we model the wage determination process. Equilibrium employment and wages are a function of union bargaining power, the unemployment benefit, and the capital stock, and in turn determine the overall labour share, wage ratio, and unemployment rate. We then aggregate these three measures into the Gini coefficient of the distribution of personal incomes for a model economy. Our highly stylised setup considers four types of agents: the jobless who receive the unemployment benefit, unskilled workers who receive the unskilled wage, and skilled workers, some of whom also own capital and receive profits. There are then three sources of inequality: employment versus unemployment, skilled versus unskilled wages, and the rewards to capital versus those to labour. In fact, the Gini index for personal incomes can be expressed as a function of the relative wage, the unemployment benefit, the labour share, and the proportion of the population in each category. This decomposition implies that the effect of labour market 
institutions on income inequality is ambiguous. For example, both higher union power and unemployment benefits increase the unemployment rate, which tends to raise the Gini coefficient, but reduce the relative wage, which tends to lower income inequality. Moreover, a higher labour share will tend to reduce income disparities between workers and capital owners, but increase those between the employed and the unemployed.

We examine these effects using data for a panel of OECD countries over the period 1960-2000. We find that greater unionization and a higher degree of wage bargaining coordination have opposing effects on inequality, implying conflicting effects of greater union presence on the distribution of income. A higher minimum wage is associated with higher inequality, as the effect of the resulting increase in unemployment on distribution dominates that of a more compressed distribution of wages. The effect of labour market institutions tends to be large, and explains a substantial fraction of the variation across countries. The capital-labour ratio also emerges as an important variable; high capital-labour ratios are associated with higher unemployment and hence with a more dispersed distribution of income.

The paper adds to the recent revival of interest in the factors shaping the distributions income across countries (see, for example, Bourguignon and Morrisson, 1990; Li et al., 1998; Alderson and Nielsen, 2002; Breen and García-Peñalosa, 2005). For decades, empirical work on income inequality consisted of either single country studies or cross-country tests of the Kuznets hypothesis taking the form of regressions of inequality on the level of GDP and its square. ${ }^{1}$ Only recently have variables other than the level of income been considered in cross-country studies, such as the level of human capital, the degree of democratisation, or the extent of financial development. These have proven useful in explaining inequality in large cross-sections of countries with very different political institutions or at very different stages of development, but cannot shed light on inequality patterns amongst the much more similar OECD economies.

\footnotetext{
${ }^{1}$ See, for example, Blinder and Esaki (1978) and Jenkins (1995) on the evolution of inequality in the US and UK, respectively, Barro (2000) for a discussion of tests of the Kuznets curve, and Parker (2000) for a discussion of the problems of time-series analysis of income inequality.
} 
Moreover, although this approach is helpful in understanding the underlying causes of inequality, it leaves little room for policy recommendations as in most cases the particular mechanism through which these variables impact inequality is not understood. By focussing on the basic determinants of the distribution of income we want to understand the underlying mechanism thought which labour market institutions impact income inequality.

Two features have dominated the recent literature on the evolution of inequality in industrial economies. One has been the increase in income inequality in a number of countries; the other the sharp rise in the relative wages in the UK and the US (Atkinson, 1997; Gottschalk and Smeeding, 1997). However, few papers have examined the determinants of both wage and income inequality. The exceptions are Gottschalk (1997), Mahler (2004) and Gottschalk and Danziger (2006). Although they account for the different evolutions of wage and income inequality, neither of them provides a unified framework in which the determination of both types of inequality can be jointly examined.

Our empirical results imply that allowing for the fact that the various forms of inequality are jointly determined has important implications. First, they indicate that although wage inequality is a crucial determinant of the distribution of personal incomes, the factor distribution of income still plays a substantial role as captured by the negative impact of the labour share in our regressions for the Gini coefficient. Second, labour market institutions can affect differently the various concepts of inequality. For example, we find that although a higher minimum wage compresses the distribution of wages, it is associated with higher income inequality because of its impact on the unemployment rate.

Lastly, our analysis is related to the extensive literature on the impact of labour market institutions on both wages and employment. A substantial number of studies have found evidence that strong labour market institutions compress wages, using both aggregate and microdata (DiNardo et al., 1996; Wallerstein, 1999; Rueda and Pontusson, 2000; Card et al., 2004; Mahler, 2004; and Koeninger et al. 2007). The evidence on the institutional determinants of 
unemployment is also extensive, and indicates that both a higher unemployment benefit and greater unionization tend to increase the unemployment rate (Nickell, 1997; Nickell et al., 2005). Bertola et al. (2002) and Baker et al. (2004) examine the impact of labour market institutions on employment inequality, while their relationship with macroeconomic variables is studied by Bowdler and Nunziata (2007), who find that greater unionization is associated with higher inflation rates in OECD countries.

The paper is organised as follows. Section 2 presents our theoretical framework. It starts with an analysis of how labour market institutions determine labour market outcomes. We then express the Gini coefficient in terms of the main labour market variables. Section 3 presents the data and our results. We then perform a number of counterfactual exercises. Section 4 concludes.

\section{Theoretical framework}

\subsection{The determinants of the relative wage, the unemployment rate, and the labour share}

\subsubsection{Technological determinants}

We consider an economy with three inputs: capital, denoted by $K$, skilled workers, $H$, and unskilled workers, $L$. Output is produced according to a constant elasticity of substitution production function using capital, $K$, and a "labour aggregate", of the form

$$
Y=\left[\alpha K^{-\sigma}+(1-\alpha)\left(H^{\beta} L^{1-\beta}\right)^{-\sigma}\right]^{-1 / \sigma} \quad \text { with }-1<\sigma<\infty, 0<\alpha<1,0<\beta<1
$$

This production function allows for different degrees of substitutability across factors. The elasticity of substitution between skilled and unskilled labour is 1, while that between capital and the labour aggregate is $1 /(1+\sigma)$. For $\sigma=0$ the production function would be Cobb-Douglas in the three inputs. In line with existing evidence, we assume that the elasticity of substitution between capital and the labour aggregate is less than one, which requires $\sigma>0 .{ }^{2}$

Differentiating the production function we obtain factor demand functions,

\footnotetext{
2 This is consistent with the evidence reported in Hamermesh (1993).
} 


$$
\begin{aligned}
& r=\alpha\left(\alpha+(1-\alpha) x^{\sigma}\right)^{-(1+\sigma) / \sigma} \\
& w_{u}=(1-\beta)(1-\alpha)\left(\alpha+(1-\alpha) x^{\sigma}\right)^{-(1+\sigma) / \sigma} x^{\sigma} \frac{K}{L} \\
& w_{s}=\beta(1-\alpha)\left(\alpha+(1-\alpha) x^{\sigma}\right)^{-(1+\sigma) / \sigma} x^{\sigma} \frac{K}{H}
\end{aligned}
$$

where $r$ is the interest rate, $w_{s}$ and $w_{u}$ are respectively the (gross) skilled and unskilled wages, and $x \equiv K / H^{\beta} L^{1-\beta}$.

The labour share, denoted $\theta$, is defined as the ratio of total employee compensation to value added. With two types of workers this is simply $\theta \equiv\left(w_{s} H+w_{u} L\right) / Y$. Defining the relative wage as $\omega \equiv w_{s} / w_{u}$, and using equations (2) we obtain the inverse relative demand for labour and the labour share as

$$
\begin{aligned}
& \omega=\frac{\beta}{1-\beta} \cdot \frac{1}{h} \\
& \theta=\frac{(1-\alpha)}{1-\alpha+\alpha x^{-\sigma}}=\left[1+\frac{\alpha}{1-\alpha}\left(k \frac{1+h}{h^{\beta}}\right)^{-\sigma}\right]^{-1}
\end{aligned}
$$

where $k=K /(H+L)$ is the capital-labour ratio and $h=H / L$ relative skilled employment. We suppose that the skilled can always work as unskilled, which ensures that the skilled wage will be greater than the unskilled one, i.e. $\omega \geq 1$. The comparative statics are straight forward, with

$$
\begin{aligned}
& \frac{\partial \omega}{\partial h}<0, \\
& \operatorname{sign}\left[\frac{\partial \theta}{\partial h}\right]=-\operatorname{sign}[\sigma(\omega-1)], \quad \operatorname{sign}\left[\frac{\partial \theta}{\partial k}\right]=\operatorname{sign}[\sigma]
\end{aligned}
$$

A higher relative employment ratio reduces the relative wage, while the impact of the capitallabour ratio and relative employment on the labour share depends on the elasticity of substitution. For $\sigma=0$, the labour share is simply $\theta=1-\alpha$, and neither $k$ nor $h$ will affect it. 
Under our assumption that $\sigma>0$ and since $\omega \geq 1$, we have $\partial \theta / \partial k>0$ and $\partial \theta / \partial h \leq 0$. That is, a higher capital-labour ratio will increase the labour share, while greater relative skilled employment will reduce both the labour share and the relative wage.

Before we proceed it is important to note that there are alternative functional forms that could have been assumed. Notably, we could have supposed an elasticity of substitution between the two types of labour different from $1,{ }^{3}$ and allowed the production function to take the more general form $Y=\left[\alpha K^{-\sigma}+(1-\alpha)\left(\beta H^{-\rho}+(1-\beta) L^{-\rho}\right)^{\sigma / \rho}\right]^{-1 / \sigma}$. The resulting wage ratio would be given by $\omega=\beta /(1-\beta) h^{-(1+\rho)}$, while $x \equiv K\left(\beta H^{-\rho}+(1-\beta) L^{-\rho}\right)^{1 / \rho}$. None of these changes would qualitatively affect our results, and hence we have chosen to use the simpler functional form in equation (1).

\subsubsection{Institutional determinants}

If labour markets were competitive, equations (3) and (4) would imply that a country's capitallabour ratio and its relative supply of skills would be the sole determinants of the labour share and the relative wage. However, labour markets are not competitive. Employment levels hence differ from factor supplies, and anything that affects employment would in turn affect $\theta$ and $\omega$.

Our focus of interest is the role of labour market institutions, and hence we consider a bargaining model. We have two types of workers, and it is often argued that skilled and unskilled wages are not determined in the same way. In particular, unskilled workers are more likely to be covered by union agreements than skilled workers, since they represent the bulk of unions' membership (see Acemoglu et al. 2001). In order to capture this difference, we suppose that skilled and unskilled wages are governed by different processes. For unskilled workers, we model the wage and employment determination process as the outcome of wage bargaining between a single union and a single firm in a right-to-manage framework. The union bargains over unskilled

\footnotetext{
${ }^{3}$ See Katz and Murphy (1992) for evidence that this elasticity is above 1.
} 
wages with the firm, and then the latter sets employment. For skilled workers, we suppose that imperfect information on the part of the firm about employees' potential shirking forces the former to pay wages above the market clearing level, as in the efficiency wage model of Shapiro and Stiglitz (1985). We suppose that workers caught shirking become unemployed, so the outside option is the unemployment benefit.

This modelling choice is driven by two considerations. First, it implies that labour market institutions will have a stronger effect on unskilled than on skilled wages. An alternative approach would be to have a single union that bargains over both skilled and unskilled wages, as in Koeninger et al. (2007). The comparative statics would be equivalent to those we will derive below, but there would be greater symmetry in the way in which institutions affect the wages and employment levels of the two types of workers. ${ }^{4}$ Second, our choice of wage determination process for the skilled is driven by the need to have a framework in which there is skilled unemployment. The question of the outside option for the skilled is important. It would have been possible to assume that skilled workers caught shirking would be fired and then find employment as unskilled labour. However, this would have implied no skilled unemployment, which would have been inconsistent with the evidence (see, for example, Nickell, 1997). ${ }^{5}$

\section{Union bargaining and the unskilled wage}

Consider first the determination of the unskilled wage and employment level. There is a single union that represents only the unskilled, and which has a utilitarian utility function of the form

$$
V=\frac{1}{\bar{L}}\left[L U\left(\widetilde{w}_{u}\right)+(\bar{L}-L) U(B)\right]
$$

\footnotetext{
${ }^{4}$ In addition, separate institutional information for skilled and unskilled workers is unavailable, and we are not convinced by the solution proposed by Koeninger et al. (2007) of considering the relative institutional variable as correlated with its level.

5 There are of course alternative ways of modelling the skilled labour market, ranging from Akerlofs (1982) gift exchange model to matching or search models, which would also lead to skilled unemployment. We believe these would have introduced greater complexity without affecting the basic results.
} 
where $\bar{L}$ is the unskilled labour force, $U($.$) is the workers' utility function, B$ is the unemployment benefit, and the net wage is given by $\widetilde{w}_{u}=(1-\tau) w_{u}$. Workers are assumed to be risk-averse with utility $U\left(\tilde{w}_{i}\right)=\tilde{w}_{i}^{\rho}$, with $0<\rho \leq 1$. The bargaining process is then governed by

$$
\max _{w_{u}}\left(L\left[\left((1-\tau) w_{u}\right)^{\rho}-B^{\rho}\right]\right)^{\gamma}\left(Y-w_{u} L-w_{s} H\right)^{1-\gamma}
$$

where $\gamma$ is the relative bargaining power of unions. The bargaining solution is obtained by maximising this expression with respect to $w_{u}$, taking into account the fact that, for a given skilled wage, changing the unskilled wage affects both skilled and unskilled employment. The resulting first-order conditions can be expressed as (see Appendix I),

$$
\rho(1-\tau)^{\rho}=\left(\frac{1-\gamma}{\gamma}(1-\beta) \frac{\theta}{1-\theta}+\varepsilon_{L}\right)\left((1-\tau)^{\rho}-\left(\frac{B}{w_{u}}\right)^{\rho}\right)
$$

where $\varepsilon_{L}$ is the elasticity of the demand for unskilled labour. Since $\varepsilon_{L}, w_{u}$, and $\theta$ are functions of $H$ and $L$, equation (7) determines $w_{u}$ as a function of skilled and unskilled employment.

\section{Efficiency wages for skilled workers}

Consider a simple, one-period efficiency wage model. Suppose skilled agents receive a net wage $\tilde{w}_{S}=(1-\tau) w_{S}$, where $\tau$ is the tax wedge paid to the government as employer and employee contributions. The expected utility of shirking is simply $U^{S}=(1-p)\left((1-\tau) w_{s}\right)^{\rho}+p B^{\rho}$ and that of not-shirking $U^{N}=\left((1-\tau) w_{s}-e\right)^{\rho}$, where $p$ is the probability of being caught if shirking, and $e$ is the monetary cost of effort. The resulting efficiency wage, $\bar{w}_{s}$, is given by the solution to

$$
\left((1-\tau) \bar{w}_{s}-e\right)^{\rho}=(1-p)\left((1-\tau) \bar{w}_{s}\right)^{\rho}+p B^{\rho}
$$


Differentiation shows that $\bar{w}_{s}$ is increasing in $B$ and $e$, and decreasing in $p$. Given $\bar{w}_{s}$ and the level of unskilled employment, the inverse demand for skilled labour, equation (2c), determines skilled employment, $H$.

\section{Equilibrium and comparative statics}

The equilibrium of the model is then given by equations (2b), (2c), (7), and (8), that is, by

$$
\begin{aligned}
& \rho(1-\tau)^{\rho}=\left(\frac{1-\gamma}{\gamma}(1-\beta) \frac{\theta}{1-\theta}+\varepsilon_{L}\right)\left((1-\tau)^{\rho}-\left(\frac{B}{w_{u}}\right)^{\rho}\right) \\
& w_{u}=(1-\beta)(1-\alpha)\left(\alpha+(1-\alpha) x^{\sigma}\right)^{-(1+\sigma) / \sigma} x^{\sigma} \frac{K}{L} \\
& \bar{w}_{s}=\beta(1-\alpha)\left(\alpha+(1-\alpha) x^{\sigma}\right)^{-(1+\sigma) / \sigma} x^{\sigma} \frac{K}{H} \\
& \bar{w}_{s}=\varphi(B, e, p, \tau)
\end{aligned}
$$

where $\varphi(B, e, p)$ is implicitly defined by (8). Together these four equations determine the equilibrium levels of skilled and unskilled employment, $H$ and $L$, and the two wages as a function of model parameters: the unemployment benefit, $B$, the bargaining power of the union, $\gamma$, the capital stock, $K$, as well as the preference parameters, $\rho$ and $e$, and the technological parameters, $\alpha, \beta, \sigma$, and $p$.

Let $u \equiv 1-(L+H) /(\bar{L}+\bar{H})$ be the unemployment rate, where $\bar{H}$ is the skilled labour force. Once $H$ and $L$ are determined, we can obtain our three main variables of interest, the labour share, the relative wage, and the unemployment rate, which we can express as functions of the stock of capital and labour market institutions: $\theta=\theta(K, B, \gamma), \omega=\omega(K, B, \gamma)$, and $u=u(K, B, \gamma)$

All comparative statics are derived in Appendix I. Consider first the effect of union power. It is possible to show that 


$$
\frac{d L}{d \gamma}<0, \quad \frac{d H}{d \gamma}<0, \frac{d u}{d \gamma}>0, \quad \frac{d \theta}{d \gamma}>0, \quad \frac{d h}{d \gamma}>0, \quad \frac{d \omega}{d \gamma}<0
$$

As in the standard wage bargaining model, the direct effect of greater union bargaining power is to reduce unskilled employment. This reduces the marginal product of skilled labour, and skilled employment falls in order to maintain the skilled wage at $\bar{w}_{s}$. Since both types of employment are reduced, the unemployment rate increases. Furthermore, under the assumption that $\sigma>0$, the labour share also increases, the reason being that lower levels of employment result in a higher capital-labour ratio. The effect of an increase in $\gamma$ on unskilled employment can be shown to be stronger than that on $H$, implying an increase in relative skilled employment, and hence a reduction in the relative wage.

Concerning an increase in the stock of capital, we have

$$
\frac{d L}{d K}>0, \quad \frac{d H}{d K}>0, \quad \frac{d u}{d K}<0
$$

A higher capital stock raises the marginal product of labour (both unskilled and skilled), leading to greater employment of both types of workers for a given wage. In the case of unskilled workers, unions react by demanding higher wages, which results in an increase in $w_{u}$. For skilled workers, given a constant efficiency wage, the increase in the capital stock leads to an expansion of skilled employment so as to maintain the marginal product of labour constant. Moreover, the indirect effects on $L$ through the change in $H$ and vice versa reinforce these direct impacts. Under reasonable conditions (see Appendix I), we can also show that

$$
\frac{d \theta}{d K}>0, \quad \frac{d h}{d K}>0, \quad \frac{d \omega}{d K}<0 .
$$

A greater capital stock has a direct positive effect on $\theta$, as a higher $K$ increases the marginal product of labour, and indirect negative impacts through the increase in both types of employment. The positive effect dominates, implying that a greater stock of capital increases the 
labour share. The effect on skilled employment can also be shown to be greater than that on unskilled employment, resulting in a higher $h$ and hence a lower relative wage.

A higher unemployment benefit has two effects. On the one hand, it increases the outside option for unskilled workers, hence unions will bargain for a higher wage and accept a lower level of employment. On the other, it increases the efficiency wages that the firm must pay to skilled workers, which requires the firm to employ fewer skilled workers in order to increase their marginal product. The reduction in $H$ tends to reduce the marginal product of the unskilled and hence partially offsets the reduction in $L$. If the direct effect dominates, so that $d L / d B<0$, it is then possible to show that

$$
\frac{d H}{d B}<0, \quad \frac{d u}{d B}>0, \quad \frac{d \theta}{d B}>0
$$

That is, a higher unemployment benefit reduces both skilled and unskilled employment, increasing the rate of unemployment and raising the labour share. The effect on the relative wage is ambiguous, as both the skilled and the unskilled wage increase.

\subsection{The Gini coefficient in a model economy}

Having established that labour market institutions affect the labour share, relative wage, and unemployment rate, we turn to their impact on the distribution of personal incomes. Our empirical measure of income inequality will be the Gini coefficient. We hence decompose this measure of inequality into its various components for a model economy with four types of agents.

The labour force (or population) is normalised to one, that is, $\bar{L}+\bar{H}=1$. Following our set-up in the previous section, workers can be either employed and receive the skilled or unskilled

wage, $\tilde{w}_{s}=(1-\tau) w_{s}$ and $\tilde{w}_{u}=(1-\tau) w_{u}$, or unemployed, in which case they receive the unemployment benefit $B$. Some individuals also own capital and receive profits. We assume that the owners of capital are always skilled workers, and that they are never unemployed. 
Furthermore, we assume that the revenue raised from employer/employee contributions, $\tau$, is used to finance the unemployment benefit, so that $B=\tau \theta y / u$. This implies that the payment of net wages, capital income, and unemployment benefit exhausts output, and average income is equal to output per capita, $y$.

We then have four types of agents characterised as follows:

(i) A fraction $u$ of the labour force are unemployed, and receive the unemployment benefit $B$

(ii) A fraction $l$ of the labour force are unskilled workers earning a net wage $\tilde{w}_{u}$;

(iii) A fraction $s$ of the labour force are skilled workers. Of those $s-\kappa$ own no capital and have an income equal to the net skilled wage $\widetilde{w}_{s}$;

(iv) There are $\kappa$ worker-capitalists, each of whom earns profits $\pi$ as well as the wage $\tilde{w}_{s}$.

Our assumptions imply that $s+l+u=1$, and that the profits of each worker-capitalist depend on the capital share, $\pi=(1-\theta) y / \kappa$. We further assume an implicit participation constraint such that $\tilde{w}_{u}>B$.

The degree of income inequality is measured by the Gini concentration index computed across subgroups of population. With $N$ subgroups, the definition of the Gini concentration index is

$$
\text { Gini }=\frac{1}{2 y} \sum_{i=1}^{N} \sum_{j=1}^{N}\left|y_{i}-y_{j}\right| \cdot n_{i} \cdot n_{j}
$$

where $y_{i}$ is the income in subgroup $i$, which has relative weight $n_{i}$, and $y$ is average income. Given our assumptions about the population and their incomes, the Gini coefficient can be expressed as

$$
\text { Gini }=(1-\kappa)(1-\theta)+l s \frac{\widetilde{w}_{s}-\widetilde{w}_{u}}{y}+u\left(\theta-\frac{B}{y}\right) \text {. }
$$


The Gini coefficient is thus a function of population proportions $(u, l, s)$, the number of capital owners $\kappa$, the labour share $\theta$, the wage differential, and the unemployment subsidy (expressed as the replacement rate with respect to per capita income). A greater wage differential between the skilled and the unskilled will raise the Gini coefficient as it increases inequality between groups of employed individuals, while a higher rate of unemployment increases inequality. The effect of the labour share is ambiguous. This is a standard effect when there is inequality within and between groups. The higher the labour share, the lower inequality between capital owners and non-capital owners is. However, a higher labour share increases the income differential between employed and unemployed individuals, and hence raises inequality within the group of non-capital owners. ${ }^{6}$

Our framework of analysis makes a number of simplifications, which are worth mentioning. First, both the distributions of wealth and of wages have been compressed, since we only have two types of workers (skilled/unskilled) and one type of wealth-owner. Second, two sources of income are missing. One are the rents on assets such as land or intellectual property rights and patents, which we ignore as they are a very minor fraction of the total. The other are government transfers other than the unemployment benefit, such as public pensions, child and housing benefits, etc. Note, however, that private pensions are implicitly included in our framework: they can be provided by pension funds, in which case they are capital income, or they can be paid by a firm to its former employees, in which case they are (most often) counted as labour payments in the company's balance sheet. Another source of income is income from selfemployment. Self-employment income will be either a reward to labour or to capital, and there is

\footnotetext{
6 The importance of within versus between group inequality is easily seen if we rewrite the Gini coefficient in an alternative way,$$
\text { Gini }=(1-\kappa)(1-\theta)+l s \frac{\tilde{w}_{s}-\tilde{w}_{u}}{y}+u(1-u) \frac{\tilde{w}-B}{y},
$$

where $\tilde{w}$ is the average net wage. This expression implies a negative effect of the labour share and an ambiguous one of unemployment. This is the effect of within versus between group inequality: the unemployed have a low income but are all equal, while the employed have a higher income but there is inequality within this group. We would expect that a higher labour share and a lower unemployment rate reduce inequality, but our Gini decompositions indicate that within group inequalities generate forces that go in the opposite direction.
} 
a controversy about how to impute this income to one or the other factor when calculating labour shares. ${ }^{7}$ Since self-employment income is unlikely to be affected by labour market institutions, in most of our analysis we do not include it in the labour share. ${ }^{8}$ Thirdly, we do not distinguish between personal income distribution and household income distribution. ${ }^{9}$ Lastly, note that we have focussed on gross income inequality, with the only tax we have considered being the unemployment insurance contribution. We also model the tax rate in a naïve way, considering immediate readjustments after a change in unemployment in order to maintain a balanced budget; available alternatives not considered here are the lowering of the replacement rate or a reduction in coverage (see Atkinson and Brandolini, 2003).

\section{Empirical Analysis}

\subsection{Empirical specification}

We saw in equation (14) that the Gini coefficient of personal incomes could be expressed as a function of the labour share, the wage premium to skill, the replacement rate, and population shares. The model identifies the determinants of employment and wages for both skilled and unskilled workers, and through them of the wage differential, the labour share, and the unemployment rate. We start by examining the determinants of these three variables. Denoting by $\theta_{i t}$ the labour share, by $\omega_{i t}$ the relative wage, and by $u_{i t}$ the unemployment rate for country $i$ in year $t$, our strategy will consist of estimating the following relationships

$$
\theta_{i t}=a_{0}+\underset{+}{a_{1} \cdot \chi_{i t}}+\underset{+}{a_{2}} \cdot b_{i t}+a_{3} \cdot \gamma_{i t}+a_{4} \cdot \mu_{i t}+\delta_{i}+\lambda_{t}+\varepsilon_{1 i t}
$$

\footnotetext{
7 See Gollin (2002).

${ }^{8}$ We checked the robustness of our estimates by using labour shares corrected for self-employment and the results did not change; see table A.7 of the previous version of this paper (Checchi and García-Peñalosa, 2005).

${ }^{9}$ Kenworthy (2007) and Esping-Andersen (2005) claim that most of the rising trend in household income inequality is attributable to changing patterns of income distribution within the family, associated with increased labour market participation of women and young people. We hence control for demographics and female participation.
} 


$$
\begin{aligned}
& \omega_{i t}=c_{0}+c_{-}^{c_{1}} \cdot \chi_{i t}+\underset{ \pm}{c_{2}} \cdot b_{i t}+c_{-} \cdot \gamma_{i t}+c_{4} \cdot \mu_{i t}+\delta_{i}+\lambda_{t}+\varepsilon_{2 i t} \\
& u_{i t}=d_{0}+d_{-}^{d_{1}} \cdot \chi_{i t}+\underset{+}{d_{2}} \cdot b_{i t}+d_{+} \cdot \gamma_{i t}+d_{4} \cdot \mu_{i t}+\delta_{i}+\lambda_{t}+\varepsilon_{3 i t}
\end{aligned}
$$

where $\chi_{i t}=\log \left(\frac{K_{i t}}{H_{i t}+L_{i t}}\right)$ denotes the $\log$ of capital per worker; $b_{i t}=\frac{B_{i t}}{\widetilde{w}_{i t}}$ is the unemployment benefit replacement rate; and $\gamma_{i t}$ captures wage-push factors, and will be proxied by union membership rates in the labour force and by the so-called Kaitz index (the ratio between the minimum wage and the median wage). The vector $\mu_{i t}$ contains a number of other variables that have been included in previous analyses of either of the three labour market outcomes. The variables $\delta_{i}$ and $\lambda_{t}$ denote country and year fixed effects, respectively. The signs reported below the coefficients to be estimated indicate the expectations derived from our theoretical model.

We lack data for some of the variables in equation (14), such as the distribution of wealth (variable $\kappa$ ) or the number of employed individuals at each level of education (variables $l$ and s). Therefore we consider the estimation of the following relationship

$$
\text { Gini }_{i t}=g_{0}+g_{1} \cdot \theta_{i t}+g_{2} \cdot \omega_{i t}+g_{3} \cdot u_{i t}+g_{4} \cdot b_{i t}+g_{5} \cdot \mu_{i t}+\delta_{i}+\lambda_{t}+\operatorname{def}_{i t}+\varepsilon_{4 i t}
$$

We also control for different definitions used to compute the Gini index (concerning the nature of the recipient unit and the type of income taken into account) with the variable $d e f_{i t}$.

The coefficient $g_{1}$ captures the relative contribution of the factor distribution of income to personal income inequality, while $g_{2}$ measures the contribution of the wage differential to overall inequality. In our highly simplified framework with workers and capitalists, $g_{1}$ can be interpreted as a measure of the between-group inequality, where groups are to be defined in accordance to their position in the production process, while the coefficients $g_{2}, g_{3}$, and $g_{4}$ can be interpreted as the contribution of inequality within the group of workers. From equation (18) we expect $g_{2}$ and $g_{3}$ to be positive, $g_{4}$ to be negative, while $g_{1}$ has a priori an ambiguous sign. 
Supposing a higher labour share reduces inequality (i.e. $g_{1}<0$ ) the effect of institutions could be positive or negative. Stronger unions tend to increase the labour share and compress the wage distribution, both of which reduce inequality. However, they also increase the unemployment rate, which raises the Gini coefficient. An increase in the unemployment benefit raises both the labour share and unemployment, and these changes have opposite effects on inequality.

Direct estimation of equation (18) is likely to yield biased coefficients, since some variables are potentially endogenous and could be correlated with unobservable and/or unmeasured variables (such as the degree of risk-aversion or the level of skilled and unskilled employment) that may also affect personal income inequality through other channels. In order to obtain unbiased estimates, we estimate the simultaneous equation system given by equations (15), (16), (17) and (18), through three-stage least squares methods.

We proceed to examine the effect of institutions in three steps. We start with OLS estimations of the effect of LMIs on the three labour outcomes. We then perform OLS and IV estimations for the Gini coefficient as a first approach to explore the correlations between labour market outcomes and income inequality. We will then introduce a 3SLS estimation of the system formed by equations (15)-(18).

\subsection{The data}

Our data cover 16 OECD countries over the period 1960-2000. Details on the data and their sources are provided in Appendix II. As is well known, the data on income inequality are problematic and international comparisons difficult (see Atkinson and Brandolini, 2001). For this reason we use two different sources for our income inequality measure: one measure is obtained from Brandolini (2003), who collected comparable measures of income inequality for several OECD countries over a sufficiently long run; the other measure is obtained from WIDER (2005), which has become the standard dataset for empirical studies of income inequality. Brandolini (2003) provides detailed information on the way in which data were collected, 
allowing us to build a series that is more comparable over time, and most of our analysis will be based on them. Unfortunately these two datasets on income inequality overlap only partially, and therefore the results are not directly comparable (see figure A.11 in Appendix III), but as a robustness check, we replicate our regression equations using the WIDER data (which build on Deininger and Squire, 1996).

Data on labour shares are from the OECD Stan Database (see figure A.12 in Appendix II). We use the standard definition of total compensation per employee over value added, without any correction for the incomes of the self-employed. This measure fits well our theoretical definition of the labour share, which comprises only the income of employed individuals. ${ }^{10}$ The wage differential is proxied by the ratio between $1^{\text {st }}$ and the $9^{\text {th }}$ decile of the earnings distribution (from OECD specific database). The earnings distribution is obtained from a labour force survey and defined in terms of annual earnings, as a result our measure of wage dispersion captures both differences in hourly wage rates and in hours worked. This is not per se a problem, since household income clearly depends on both hours worked and wage rates, although it implies that the concept of wage inequality used is not exactly equivalent to that used in the model in section 2. The alternative would have been to use the decile ratio of the distribution of hourly wages, the measure commonly used when examining the evolution wage inequality in a particular country. Unfortunately, such a variable is not readily available in a comparable form across countries.

Standard datasets were use to obtain information on labour market institutions and other variables. The latter comprise the oil price, capital per worker, trade openness (measured as the ratio of imports plus exports to GDP), average years of education, female labour force participation, the proportion of the adult population aged 65 or more, and social security transfers as a proportion of GDP (see Appendix II for details).

\footnotetext{
${ }^{10} \mathrm{It}$ is important to note that the labour share as obtained from national account tends to be much lower than the share of labour earnings in personal income. Our companion paper examines how labour market institutions affect the share of labour earnings and through them income inequality. See Checchi and García-Peñalosa (2008).
} 
Table A.1 in Appendix III reports some descriptive statistics for the main variables in our regressions. Data on income inequality are collected infrequently; hence our sample is largely determined by the availability of information on the Gini coefficient, but also by the availability of data on wage differentials. Although the potential sample size is 640 observations (16 countries $\times 40$ years), the overlapping between information on the Gini index and wage differentials reduced the sample to 130 observations, which cover only 11 countries. ${ }^{11}$ The panel is unbalanced, with countries having between 3 and 37 observations. The US, the UK, Germany, Sweden, Italy, and Canada have the most observations. In order to obtain as much information as possible from the limited available data we run regressions both for the largest possible sample (with non missing observations on income inequality) and for the common 130-observation sample.

Table A.3 reports the descriptive statistics of our entire dataset, whereas table A.4 shows the correlation matrix among the same variables. There it is possible to see that income inequality exhibits an (unconditional) correlation with labour market outcomes (labour share, wage differential, unemployment rate) but with only with some of the labour market institutions (namely, the unemployment benefit and minimum wage) and not with others (union density, bargaining coordination, and the tax wedge).

\subsection{Determinants of labour market outcomes}

Table 1 examines the determinants of the labour share and presents three alternative specifications: without fixed effects, with country fixed effects, and with country and year fixed

11 A larger sample (236 observations) is obtained when we restrict ourselves to the available observations on income inequality (Brandolini), labour share and unemployment (see table A.1). As it can be seen from table A.2, a significant drop in the number of observations is caused by the lack of observations in the decile ratio. In order not to loose information, when using this variable as regressor we replace missing observations with sample averages computed over countries. However, when this variable is considered as a dependent variable, the intersection of non-missing information for all variables decline to 137 observations, which is then reduced to 130 by excluding countries with 1 or 2 observations. 
effects. These specifications are estimated for both the largest available sample and the common sample.

In column 1 we find that the labour share is increasing in union density rates, but this effect disappears when country fixed effects and cyclical factors are properly accounted for using year fixed effects (columns 2 and 3). The coefficient on the minimum wage is also unstable across specifications. ${ }^{12}$ Similarly, the unemployment benefit has a negative but not always significant correlation with the labour share. The reason for this is likely to be that all three institutions tend to both increase wage -which tends to increase the labour share- and reduce employment -which tends to reduce it-. Our regression results indicate that these two effects cancel each other out. The only institution that has a robust coefficient across specifications and samples is the degree of bargaining coordination, with greater coordination being associated with a higher labour share.

The capital/labour ratio has a positive, large and significant effect on the labour share, as implied by our model. We include the price of oil in national currency in order to capture exogenous shocks to raw materials prices (this variable also captures the effect of competitive devaluations, and the J-effect on internal inflation). The oil price has an unstable coefficient, that changes sign across specifications and loses significance in the common sample. Lastly, we have considered the potential role of the supply of skills. Time series of labour force composition by skills are not available over a long enough time span, therefore we use proxies derived from measures of educational attainment. The one reported in the text is the average years of education in the adult population, but the enrolment rate has a similar effect. Once country fixed effects are included, the education variable displays a negative coefficient, suggesting that as the number of skilled individuals increases, the unemployment rate of the skilled rises, reducing the incentives to shirk and hence allowing firms to pay a lower skilled wage that in turn reduces the wage bill.

12 Using the level of the minimum wage as an explanatory variable is problematic, as it is missing for several countries (Denmark, Finland, Germany, Italy, Norway, Sweden and UK for most of the sample period). In order not 


\section{Tables 1, 2 and 3 approximately here}

Our results are in line with those obtained in earlier work. Bentolila and Saint Paul (2003), who consider sectoral data for 12 countries over a shorter time span, find a significant correlation between the labour share (corrected for self-employment) and the capital-output ratio, strike activity, employment adjustment costs (proxied by previous changes in employment) and total factor productivity, whereas the oil price is found to be statistically insignificant. While the sign of the coefficient on the capital-output ratio varies across sectors (depending on the degree of substitutability or complementarity between factors), they find a weakly significant negative coefficient on strike activity, which they interpret as lagged responses to wage push factors. Blanchard (1997) finds that labour share movements are mainly affected by supply shocks, with significant reaction lags. Our results hence support the traditional view that factor shares respond to relative factor endowments (here proxied by capital per worker) but that there is evidence that wage push factors, captured by bargaining coordination, also play a significant role.

In table 2 we report the determinants of the wage differential. We find no evidence of a correlation between factor endowments, measured by capital per worker, and the decile ratio, probably the result of different degrees of complementarity between capital and labour across sectors. An increase in skill availability in the labour force (proxied by our human capital variable) tends to depress the relative wage, and indeed we find a negative coefficient on this variable, although it looses its significance when we include year fixed effects. We find a strong and significant impact of labour market institutions. Not surprisingly, the minimum wage reduces wage differentials. The unemployment benefit, which according to the model has an ambiguous effect as it increases both skilled and unskilled wages, seems not to be correlated with wage

to loose degrees of freedom, we have replaced the missing observation with a unitary value, which is cleared away with the country fixed effect. 
dispersion. Bargaining coordination and union density also have negative and significant coefficients. The time trend exhibits a positive and significant coefficient in columns 2 and 4, capturing the upwards trend in earnings inequality, potentially associated to skill-biased technical change. Note also that the coefficients are robust to the change in the sample.

Koeninger et alt. (2007) study wage inequality in a framework similar to ours, estimating the determinants of the P90/P10 ratio for 11 countries over a similar time interval. Our results are consistent with their analysis, since both papers find that stronger labour market institutions compress wage differentials. ${ }^{13}$ In contrast to us, Koeninger at al. (2007) include as regressors import penetration and R\&D intensity to account for skill-biased technological change without finding robust effects. ${ }^{14} \mathrm{We}$ limit ourselves to a linear time trend, which is identical across countries and bears a positive coefficient. Strong evidence of the effect of unionisation on relative wages has also been found by Wallerstein (1999), Rueda and Pontusson (2000), and Mahler (2004).

Lastly, table 3 examines the institutional determinants of unemployment. Union density and the minimum wage are positively correlated with unemployment, while bargaining coordination presents a negative correlation, a result also found in recent work (Nickel, Nunziata and Ochel, 2005; Bassanini and Duval, 2006). Contrary to our expectations, the coefficient on the unemployment benefit is not significant in this equation, while the tax wedge has a negative association. ${ }^{15}$ Note, however, that the coefficient on the unemployment benefit is significant when we do not include country dummies suggesting that the positive correlation found in previous work (see, for example, Nickell, 1997) is mostly attributable to cross-country variations.

\footnotetext{
13 This is also consistent with micro-data analysis; see DiNardo et al. (1996) and more recently Card et al. (2004).

14 A further difference with their analysis is that they consider employment protection. While in their theoretical model they assume that skilled and unskilled workers should face different firing cost, due to the lack of data in the empirical analysis they resort to the unique series available, produced by OECD. However this series exhibit little variation across years, as witnessed by its statistical insignificance when first differences are considered. For this reason we have decided not to include EPL into our regressions.

15 While the standard expectation is of a positive sign (because a higher tax wedge under wage bargaining leads to net wage resistance, and therefore increases labour costs and decreases employment), general equilibrium consideration may lead to the opposite effect (see Corneo, 1995).
} 
While other inequality variables exhibit substantial inertia, unemployment responds to business cycle fluctuations, which in econometric modelling is often captured by AR and/or MA components. However, given that inequality data are available at irregular intervals, we have been unable to provide a fully satisfactory account of the data-generating-process underlying unemployment dynamics. ${ }^{16}$

Macroeconomic variables, such as capital per worker and openness tend to have insignificant coefficients, while higher female participation rates are associated with lower unemployment, probably capturing the fact that the female labour supply is more elastic to labour market conditions than the male labour supply. The time trend exhibits a positive coefficient that, in the larger sample, retains its significance even when year fixed effects are included. This coefficient seems to capture an upward trend in unemployment which is not explained by changes in labour market institutions.

To sum up, to a large extent our results are consistent with previous work and indicate that labour market institutions are significantly correlated to labour market outcomes. Bargaining coordination has an impact on all three labour market outcomes, union density rates and the minimum wage affect both wage inequality and unemployment, while the unemployment benefit seems not to be correlated with labour market outcomes once country fixed effects are included.

\subsection{The determinants of personal income inequality}

We move next to the determinants of personal income inequality. Table 4 reports our estimates of equation (18). The first four columns report our results for the largest available sample, and the next four those for the common sample. The $1^{\text {st }}$ and $3^{\text {rd }}$ columns abstract from year fixed effects, which are subsequently included in the $2^{\text {nd }}$ and $4^{\text {th }}$ columns; a linear time trend and

\footnotetext{
16 The poor time-series nature of our data has prevented us from being able to use data on macroeconomic shocks and lagged unemployment that have been shown to be important when explaining unemployment. See Bertola et al. (2002) and Nickell et al. (2005). We also find an insignificant correlation between unemployment and the benefit in Checchi and García-Peñalosa (2008).
} 
dummies controlling for changes in definitions are also included. ${ }^{17}$ We estimate the equation for Gini using both OLS and IV estimation. Based on previous results on the determinants of labour market outcome, we use as instruments bargaining coordination, union density, minimum wage and capital per worker. The IV coefficients differ markedly from those obtained in the OLS estimations, indicating that the OLS coefficients are biased, possibly due to unobservable components affecting income inequality. Results are consistent across the two samples, although the coefficients are of somewhat smaller absolute value in the common sample.

\section{Table 4 approximately here}

The labour share has a negative coefficient, indicating that the between group effect dominates, while the wage differential has a positive coefficient. ${ }^{18}$ The unemployment rate and the unemployment benefit, however, have insignificant coefficients in some specifications. When we look at the additional explanatory variables we see that only the population share over 65 years of age has a consistently significant coefficient, with a greater fraction of aged individuals being associated with lower inequality. This variable has an a priori ambiguous sign, due to the opposing effects of an older population on between-group and within-group inequality. The negative coefficient implies that the within-group effect dominates, and captures the fact that the incomes of retired households are more equally distributed than those of working households. Surprisingly, social security transfers are only significant in the OLS estimates for the largest sample and have a positive sign. There is weak evidence that a more educated labour force is associated with greater inequality, while we find no impact of (our measure of) openness on the

\footnotetext{
17 The controls for definition include whether the income is gross or net, and whether the recipient is household equivalent or person equivalent. We also experimented with errors clustered by countries, without significant changes (results are available from the authors).

18 Kenworthy (2004) uses household income inequality and personal earnings inequality (proxied by p90/p10 ratio) computed from LIS (Luxemburg Income Study), with one observation for 14 countries. When regressing the former onto the latter, he finds a coefficient comprised between 0.61 and 0.68 , depending on various specifications, which is much lower than our figures. However sample size and the countries included are not comparable.
} 
distribution of household incomes. Diagnostic tests on the instrumental variable estimation indicate that our first stage specifications are appropriate for the labour share and the wage differential, while the unemployment equation may have problems (possibly because we imperfectly control for labour supply and labour demand shocks). The set of instruments passes the overidentification test in the larger sample, without converging in one specification of the common sample.

\section{Figure 1 approximately here}

Our results indicate that year fixed effects are highly significant and have substantial explanatory power (as can be seen by the increase in the $R^{2}$ once we include them). Figure 1 reports the year fixed effects obtained in table 4, column 2. These fixed effects capture the trend over time in income inequality averaged across our sample of countries. This trend account for 2.5 Gini points, which is about a third of the standard deviation of our inequality variable. Figure 1 shows that there was a sharp but temporary jump in inequality between the mid-1970s and 1980, and, starting in 1984, ten years of gradually increasing inequality. Rather than long-run trends, these fixed effects illustrate the idea that there are "episodes" of increasing or decreasing inequality, as suggested by Atkinson (2007).

In table 5 we report the coefficients obtained when we estimate the simultaneous equation system defined by equations (15), (16), (17) and (18) through three-stage least squares. ${ }^{19}$ Our three endogenous variables, the labour share, wage differential and unemployment rate, are all correlated with income inequality. The main difference with the estimates of table 4 - both OLS and IV - is that the unemployment rate, which was previously insignificant, now has a

\footnotetext{
${ }^{19}$ Each equation is identified by one or more variables: the Gini inequality index by compositional variables (share of female employment and older population, and welfare size), labour share by oil price, wage differential by educational attainment and unemployment rate by the tax wedge. This identification strategy has been driven by consistency with our theoretical model as well as by statistical significance. Note that it has forced us to remove our measure of education from the labour share regression.
} 
significant and large correlation with inequality, as found in some other work (Blinder and Esaki, 1978). The unemployment benefit, on the other hand, is not significantly correlated with inequality. All three labour market outcomes have an economically significant effect. The wage differential exhibits the strongest correlation: an increase of one standard deviation in the P90/P10 ratio is associated with an increase in the Gini coefficient of over 11 points. An equivalent increase in the labour share reduces inequality by 4 points, and in the unemployment rate raises inequality by 5.7 points. Concerning the additional explanatory variables, demographic characteristics seem to play little role, while we now find the expected negative and significant coefficient on social security transfers. The coefficient on export-imports indicates that more open economies exhibit a less dispersed distribution of income.

\section{Table 5 approximately here}

The equation for the determination of the labour share (column 2) is consistent with what we have already found in the least square estimation (table 1). The wage differential falls with higher union density, bargaining coordination, and minimum wage, in line with the OLS estimates reported in table 2. Factor endowments are important, with a more educated labour force reducing the wage differential and a greater stock of capital increasing both the labour share and the decile ratio.

The unemployment equation also reproduces our previous results. The unemployment benefit has no significant effect, while higher union density and minimum wage are positively correlated with the unemployment rate. The tax wedge retains its negative sign. The fit of the unemployment equation is worse than for the other labour market outcomes (the $R^{2}$ is 0.81 ). The reason for the poor results could be that unemployment is more volatile than the other variables (wits cyclical dynamics is not perfectly captured by our model, at least in the case of Italy and the Netherlands: see figure A.7). Given that inequality data is often available at irregular 
intervals, we do not have good enough time series information to enable us to capture well the dynamics of unemployment. Note that, as in the last column of table 4, a greater stock of capital is associated with higher unemployment. This raises the question of the exogeneity of the capital stock, as a possible explanation for the sign of this coefficient is that institutions that make labour expensive induce firms to substitute capital for labour, resulting in both higher unemployment and a larger stock of capital.

Overall we find that when we allow for the joint determination of the three labour market outcomes and inequality the unemployment rate, which previously exerted no impact on the Gini coefficient, now has a positive and highly significant coefficient, as predicted by the theory. All institutions, except the unemployment benefit, exhibit a significant relationship with inequality. Two of them - bargaining coordination and the tax wedge - are negatively correlated with

income inequality, while the other institutions - union density and the minimum wage- are positively correlated.

\section{Figure 2 approximately here}

The predictive ability of the model is good, as can be seen from figure 2 that compares the actual and the predicted dynamics of the Gini index (see also figures A.5, A.6 and A.7 in Appendix III). This is rather impressive if one considers the block recursive nature of the model, noting that in addition to its own prediction error, the prediction for the Gini index accumulates the prediction errors from the other three endogenous variables. In particular our model captures the trend reversal in income inequality observed in most European countries at the end of the 1970s (notably the Netherlands, France and United Kingdom), which seems to be largely explained by the contemporaneous decline in the labour share.

A number of robustness checks are reported in Appendix III. A first possible concern is that the inequality series are non-stationary. A Dickey-Fuller test (reported in table A.8 for the 
version with constant, without time trend and with one lag - similar results are obtained when varying these patterns) indicates that there is a variety of patterns across countries, with some series being stationary in levels, others in first differences, and others in neither of the two forms. In addition, for a few countries it is impossible to assess stationarity due to the discontinuity of the series There seems therefore to be no reason to prefer estimating the model in first differences, although we run such regressions nevertheless, the results being reported in table A.9, where we still find evidence of a significant correlation for the labour share and the wage differential, although somewhat weaker. We also consider alternative data on income inequality, and perform a 3SLS using Gini coefficients obtained by WIDER and find comparable results; see table A.10 in the appendix.

\subsection{Changes in institutions}

Putting together the results from our four equation system, and being aware that our regressions can capture a causal relationship if and only if our LMIs were fully exogenous, we can examine the different impact that the various institutions have on inequality. Our estimates indicate that:

(i) greater bargaining coordination increases the labour share and reduces the wage ratio, both of which result in a more dispersed distribution of income;

(ii) a higher minimum wage is associated with a lower wage ratio and a higher rate of unemployment, which have offsetting effects on inequality;

(iii) greater union density tends to reduce inequality as it results in a lower wage ratio, while its effect through the rate of unemployment tends to increase it;

(iv) a higher tax wedge decreases unemployment and hence inequality;

(v) we find no evidence of a robust effect of the unemployment benefit on inequality.

The estimated coefficients reported in table 5 do not provide us with the magnitude of the correlations between the relevant variables, especially when taking into account the opposite effects associated with different intermediate inequality measures. For this reason, we have 
carried out an exercise, reported in table 6, consisting of computing the effect on the Gini index and the intermediate inequality variables of increasing each of the explanatory variables by one standard deviation. ${ }^{20}$ We use the 3SLS estimates of table 6 and report the resulting impact as a proportion of the standard deviation of the endogenous variables.

\section{Table 6 approximately here}

Union presence - measured by union density and wage bargaining coordination - has two opposing effects on inequality. On the one hand, greater bargaining coordination increases the labour share and reduces the wage ratio, tending to reduce inequality. On the other, greater union density increases unemployment which tends to increase inequality (although this effect is reduced by the fact that higher density reduces the wage ratio). The table highlights the trade-off that emerges between union density, which tends to increase inequality, and wage bargaining, which tends to reduce it. Although the opposite sign of the impact of certain institutions on employment and average wages has already been identified (for example Bertola et al., 2001), what is novel here is the focus on income inequality. Since institutions often move together - as is the case of union density and wage bargaining coordination - the question of how labour market reforms would impact on inequality becomes difficult to answer. The estimated coefficients imply that the equalizing effect of bargaining coordination is weaker than the unequalizing impact of density.

As we have seen, the minimum wage has an a priori ambiguous effect on inequality due to its offsetting effects on the wage ratio and unemployment. Our estimates indicate that the effect through unemployment dominates, implying that a higher minimum wage tends to increase inequality. This institution has the strongest impact on inequality. An increase in the minimum wage by one standard deviation raises inequality by 1.3 standard deviations, i.e. by 9.6 Gini

20 These effects are computed by using all the estimated coefficients reported in table 5, irrespective of their 
points. The tax wedge also has a large impact on inequality, reducing the Gini coefficient by almost one standard deviation.

The two types of capital have strong correlations with income inequality, with the overall impact being positive for physical capital and negative for human capital. A higher capital-labour ratio increases the labour share but also unemployment, and the overall effect is to widen income dispersion. Meanwhile, a more educated labour force leads to a lower skill premium, implying that more education is associated with less income inequality. ${ }^{21}$ The magnitude of these two effects is roughly the same, with an increase in one standard deviation in capital per worker and in years of education resulting in a change of 4 and -4.3 Gini points, respectively. An equivalent increase in trade openness reduces inequality by 4.6 points. Higher oil prices induce a large reduction in the labour share, which results in a particularly strong impact on inequality: the Gini coefficient increases by almost one standard deviation.

\subsection{Counterfactual exercises}

We have performed two counterfactual exercises to assess the importance of the various labour market variables. Such exercises need to be interpreted with care as we are implicitly assuming the exogeneity of institutions.

To illustrate the process, consider figure 3 which depicts income inequality and the three labour market outcomes in Germany. Using the estimated coefficients in table 5, we have obtained the predicted values for the labour share, wage differential and unemployment rate for all the country/year observations available in the sample. We then use these values to further predict the Gini coefficient. The figure shows, in addition to the standard prediction (continuous line), the predicted value for the four endogenous variables obtained when we replace German

statistical significance, otherwise the predicted value would be different from the sample mean.

21 Barro (2000) finds a negative correlation between inequality and secondary school enrolment and a positive correlation with tertiary enrolment; these findings are difficult to compare with ours, since we have a stock measure, combining three levels of educational attainment. 
labour market institutions with British ones (long-dashed line). The figure illustrates that income inequality in Germany would have been between 8 and 10 Gini points higher if it had experienced the same institutions as the UK. Higher inequality would be the result of a lower labour share, especially towards the end of our sample period, and a higher rate of unemployment. Note that these simulations contradict the perception that higher inequality is associated with lower unemployment, as the rate of unemployment itself is a crucial element determining the degree of household income inequality.

\section{Figures 3 and 4 approximately here}

In figure 4 we obtained the predictions for our four variables of interest for the UK, using both British institutions (continuous line) and Finnish ones (long-dashed line). The overall effect is a reduction in the Gini coefficient of between 9 and 10 points. This is almost twice the average difference in the actual Gini between the two countries, which is of 5.6 points. The sharp decline in inequality is the effect of much greater union density and bargaining coordination in Finland, that results in a major reduction in wage inequality. Changes in the labour share play little role (recall that union density and coordination have opposite effects on the labour share), while unemployment is higher with Finish institutions only in the latter years.

\section{Conclusions}

The recent literature on the determinants of personal income inequality has emphasized the role of a number of factors such as globalisation, financial development, and political stability. These variables help us explain distributional differences in a large cross-sections of countries, but have little explanatory power when trying to understand differences across the rather similar OECD economies. In this paper we have argued that labour market institutions play an essential role in explaining differences in inequality within the OECD, both across countries and over time. 
We highlight the different channels through which labour market institutions affect inequality. These institutions affect simultaneously relative wages, the labour and capital shares, and the unemployment rate, and hence the distribution of personal incomes, but their overall impact is a priori ambiguous. We have found that labour market institutions significantly affect income inequality, but that different institutions operate through different channels. Union presence has two opposing impacts. On the one hand, greater union density increases the unemployment rate and hence income inequality. On the other, greater bargaining coordination reduces the wage differential and increases the labour share, both on which tend to make the distribution of income more dispersed. The minimum wage is the institution that exhibits the strongest correlation with inequality. A higher minimum wage compresses the distribution of earnings, which tends to reduce the Gini coefficient, but raises unemployment, which tends to increase it. Our estimates indicate that the latter effect dominates, resulting in a positive correlation between the minimum wage and income inequality. To our surprise we found no evidence of either a direct or an indirect effect of the unemployment benefit on the distribution of income.

Together with labour market institutions, factor endowments have a strong impact on distribution. A higher capital-labour ratio increases the labour share, but also the wage differential and unemployment, and the overall impact is to raise income inequality. Meanwhile, a more educated labour force results in a lower skill premium, leading to a less dispersed distribution of income, while greater trade openness tends to have a direct negative impact on inequality. A caveat is, however, in order. Our analysis is static and takes both the degree of openness and the stock of physical and human capital as given. This implies that we are ignoring the potential impact of labour market institutions on capital formation and trade patterns. These are important questions that remain to be addressed in future work. 


\section{References}

Acemoglu, D., Aghion, P. and Violante, G. (2001). Deunionization, Technical Change and Inequality. Carnegie-Rochester Conference Series on Public Policy, 55, 229-264

Akerlof, G. (1982). Labor contracts as partial gift exchange. Quarterly Journal of Economics, 1982, 543-69.

Alderson, A. and Nielsen, F. (2002). Globalisation and the great U-turn: Income inequality trends in 16 OECD countries. American Journal of Sociology, 107, 1244-1299.

Antras, P. (2004). Is the U.S. Aggregate Production Function Cobb-Douglas? New Estimates of the Elasticity of Substitution, Contributions to Macroeconomics, 4, article 4.

Atkinson, A.B. (1997). Bringing the Income Distribution in from the Cold. The Economic Journal, 107, 297-321.

Atkinson, A.B. (2007). Distribution and growth in Europe - the empirical picture, a long-run view of the distribution of income. Mimeo.

Atkinson, A.B. and Brandolini, A. (2001). Promise and Pitfalls in the Use of Secondary Data-Sets: Income Inequality in OECD Countries as a Case Study. Journal of Economic Literature, 39, 771-99.

Atkinson, A.B. and A. Brandolini. (2003). The Panel-of-Countries approach to explaining income inequality: an interdisciplinary agenda. Mimeo

Baker, D., Glyn, A., Howell, D., and Schmitt, J. (2004). Labor Market Institutions and Unemployment: A Critical Assessment of the Cross-Country Evidence. In D. Howell (ed.), Fighting Unemployment, The Limits of Free Market Orthodoxy, Oxford, Oxford University Press.

Barro, R.J. and Lee, J.-W. (1993). International Comparisons of Educational Attainment, Journal of Monetary Economics, 32, 363-94.

Barro, R.J., (2000), Inequality and Growth in a Panel of Countries, Journal of Economic Growth, 5, 532. 
Bassanini, A. and Duval, R. (2006). Employment patterns in OECD countries: reassessing the role of policies and institutions. OECD Economics Department working papers no. 486

Bentolila S. and Saint-Paul, G. (2003). Explaining Movements in the Labor Share, Contributions to Macroeconomics, 3, article 9.

Bertola, G., Blau, F. and Kahn, L. (2002). Comparative Analysis of Labor Market Outcomes: Lessons for the US from International Long-Run Evidence. In A. Krueger and R. Solow (eds.), The Roaring Nineties, Can Full Employment be Sustained?, Russell Sage and Century Foundations.

Blanchard, O., (1997). The Medium Run. Brookings Papers on Economic Activity, 2, 89-158.

Blinder, A.S. and Esaki, H.Y. (1978). Macroeconomic Activity and Income Distribution in the Postwar United States. Review of Economics and Statistics, 60, 604-609.

Bourguignon, F. and Morrisson, C. (1990). Income distribution, development and foreign trade: a cross-section analysis, European Economic Review, 34, 1113-32.

Bowdler, C. and Nunziata, L. (2007). Trade Union Density and Inflation Performance: Evidence from OECD Panel Data, Economica, 74, 135-159.

Brandolini, A. (2003). A bird-eye view of long-run changes in income inequality. Bank of Italy, mimeo.

Breen, R. and C. García-Peñalosa. (2005). Income Inequality and Macroeconomic Volatility: An Empirical Investigation. Review of Development Economics, 9, 380-98.

Card, D., Lemieux, T. and Riddel, W.C. (2004). Unions and Wage Inequality Journal of Labor Research. 25, 519-562.

Checchi, D. and García-Peñalosa, C. (2005). Labour shares and the personal distribution of income in the OECD. IZA Discussion Paper No. 1681/2005.

Checchi, D. and García-Peñalosa, C. (2008). Labour Market Institutions and Income Inequality. Economic Policy, 56, $601-649$. 
Cohen, D. and Soto, M. (2007). Growth and human capital, good data, good results. Journal of Economic Growth, 12, 51-76.

Corneo, G. (1995). National wage bargaining in an internationally integrated product market. European Journal of Political Economy, 11, 107-116.

Daudey, E. (2005). The Sharing of Value-Added, Data Sources. Mimeo, GREQAM.

Deininger, K. and Squire, L. (1996). Measuring income inequality: A new data base, The World Bank Economic Review, 10, 565-591.

DiNardo, John, Fortin, N.M. and Lemieux, T. (1996). Labor Market Institutions and the Distribution of Wages, 1973-1992: A Semi-Parametric Approach. Econometrica 64, 1001 1044.

Esping-Andersen, G. (2005). Inequality of incomes and opportunities. In A. Giddens and P.Diamond (eds), The new egalitarianism, 8-38.

Gollin, D. (2002). Getting Income Shares Right. Journal of Political Economy, 110, 458-474.

Gottschalk, P., (1997). Policy Changes and Growing Earnings Inequality in the US and Six Other OECD Countries. In P. Gottschalk, B. Gustafsson and E. Palmer (eds.), Changing Patterns in the Distribution of Economic Welfare. An International Perspective, Cambridge, Cambridge University Press.

Gottschalk, P. and Danziger, S. (2006). Inequality of wage rates, earnings and family income in the United States, 1975-2002. Review of Income and Wealth, 51, 231-254.

Gottschalk, P. and Smeeding, T.M. (1997). Cross-National Comparisons of Earnings and Income Inequality. Journal of Economic Literature, 35, 633-687.

Hamermesh, D.S. (1993). Labor Demand. Princeton, NJ, Princeton University Press.

Jenkins, S.P. (1995). Accounting for Inequality Trends: Decomposition Analyses for the UK, 1971-86. Economica, 62, 29-63.

Katz L.F. and Murphy, K.M. (1992). Changes in Relative Wages, 1963-1987: Supply and Demand Factors. Quarterly Journal of Economics, 107, 35-78. 
Kenworthy, L. (2007). Explaining comparative trends in income inequality in the 1980s and 1990s, chapter 3 in Egalitarian Capitalism: Jobs, incomes and Growth in Affluent Countries. Russell Sage Foundation, New York.

Koeninger, W., Leonardi, M. and Nunziata, L. (2007). Labour market institutions and wage inequality, Industrial \& Labor Relations Review, 60, 340-356.

Li, H., Squire, L. and Zou, H-F. (1998). Explaining International and Intertemporal Variations in Income Inequality. The Economic Journal 108, 26-43.

Mahler, V. A. (2004), Economic Globalization, Domestic Politics and Income Inequality in the Developed Countries: A Cross-National Study, Comparative Political Studies, 37, 1025-1053.

Nickell, S. (1997), Employment and labor market rigidities: Europe versus North America. Journal of Economic Perspectives, 11, 55-74.

Nickell, S. and L. Nunziata. (2001). Labour market institutions database

Nickell, S., L. Nunziata and W. Ochel. (2005). Unemployment in the OECD since the 1960s. What do we know? The Economic Journal 115, 1-27.

OECD 2002. Benefits and wages - OECD indicators. Paris.

Parker, S.C. (2000). Opening a Can of Worms: The Pitfalls of Time-Series Regression Analysis of Income Inequality. Applied Economics 32, 221-230.

Rueda, D., and Pontusson, J. (2000), Wage Inequality and Varieties of Capitalism. World Politics, $52,350-383$.

Shapiro, C. and Stiglitz, J.E. (1984). Equilibrium Unemployment as a Worker Discipline Device. American Economic Review, 74, 433-444.

Summers, R. and Heston, A. (1991). The Penn World Table (Mark 5): An expanded set of international comparisons,1950-1988. Quarterly Journal of Economics, 106, 327-368.

Wallerstein, M., (1999). Wage-Setting Institutions and Pay Inequality in Advanced Industrial Societies. American Journal of Political Science, 43, 649-680. 
WIDER, 2005. World Income Inequality Data Base. Dataset available at www.wider.unu.edu/wiid/wiid.htm. 
Figure 1 - Estimated year fixed effects, from table 4 - Gini index on income inequality

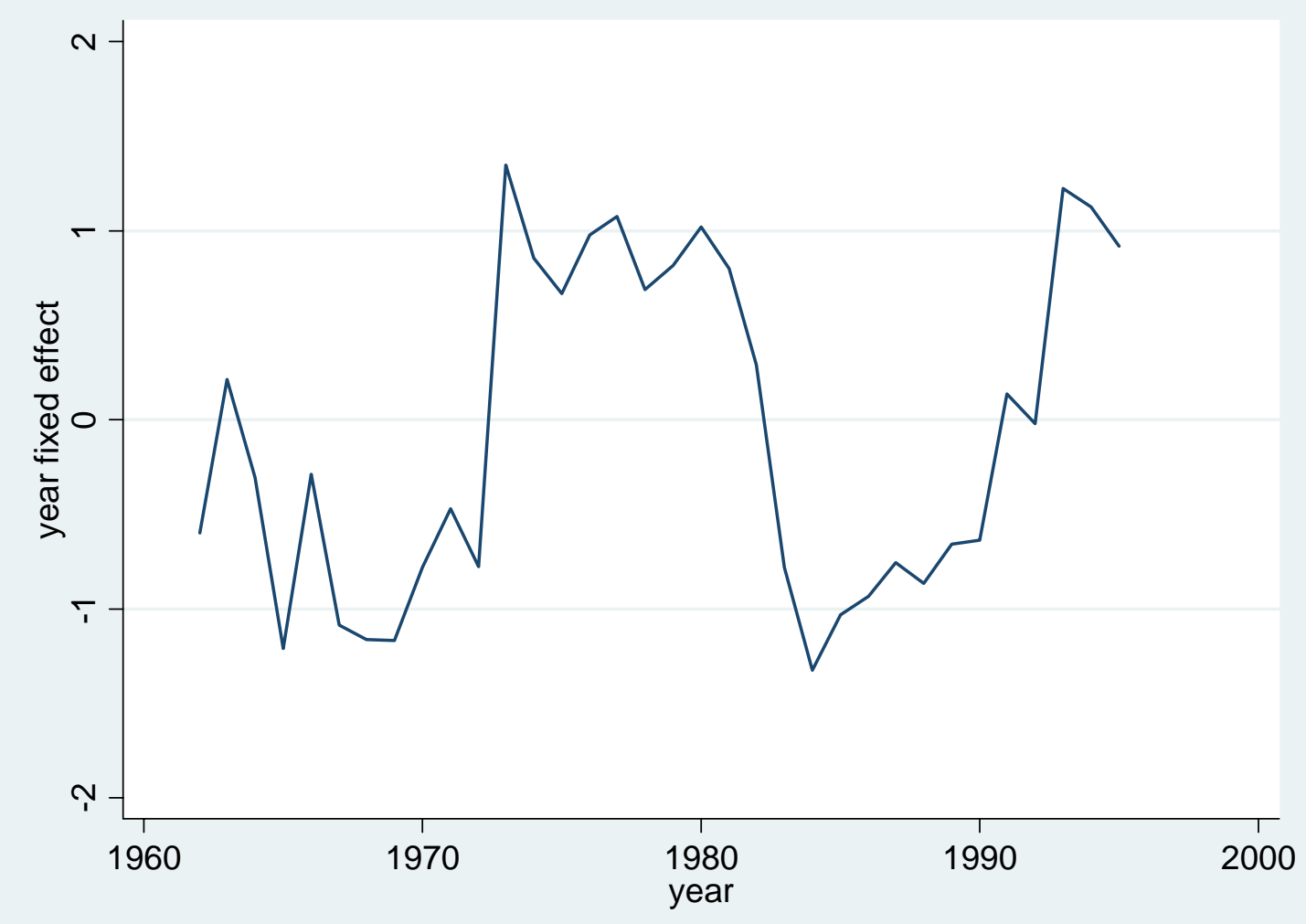

Figure 2 - Predictive ability of the model estimated in table 5 - Gini index on income inequality

\section{Gini index - Bradolini 2003}
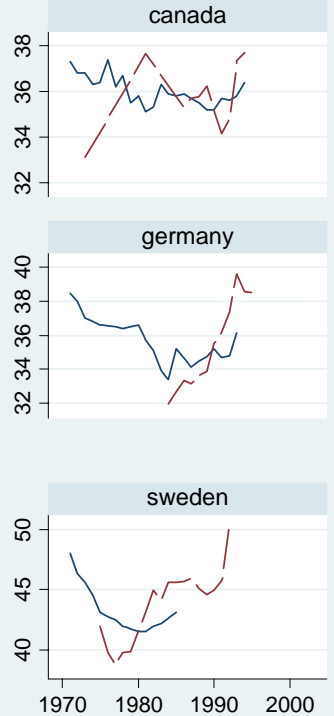

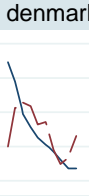

italy

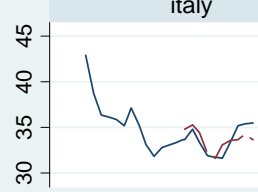

united kingdom

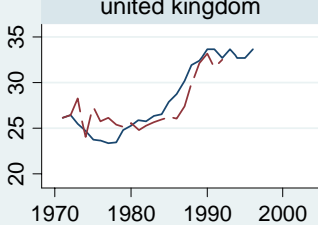

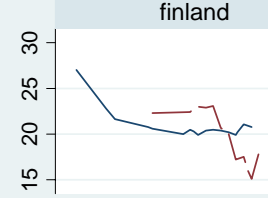

netherlands

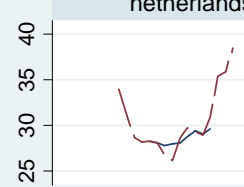

united states

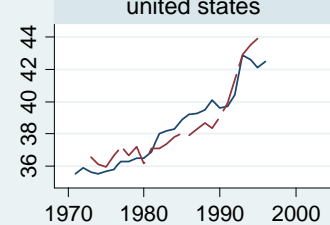

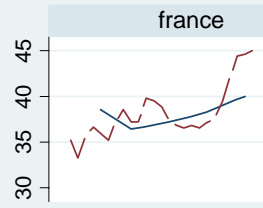

norway

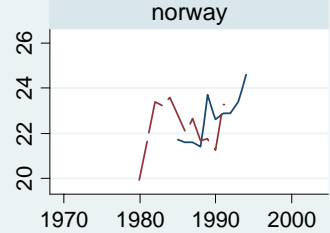

year

actual - - predict 
Figure 3 - Counterfactual 1: Germany with UK labour market institutions

\section{Germany under British institutions}
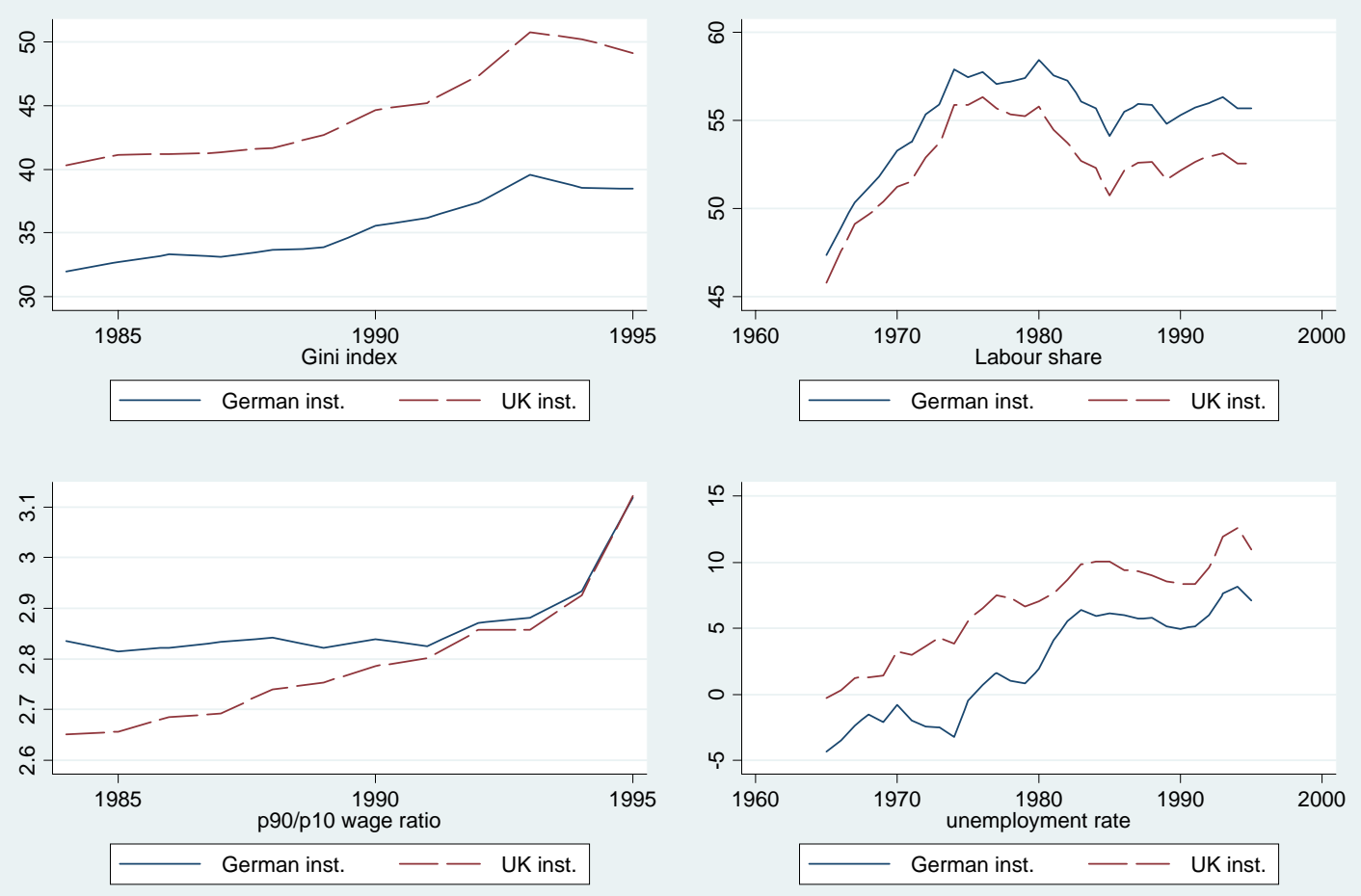

Figure 4 - Counterfactual 2: UK with Finnish labour market institutions

\section{United Kingdom under Finnish institutions}
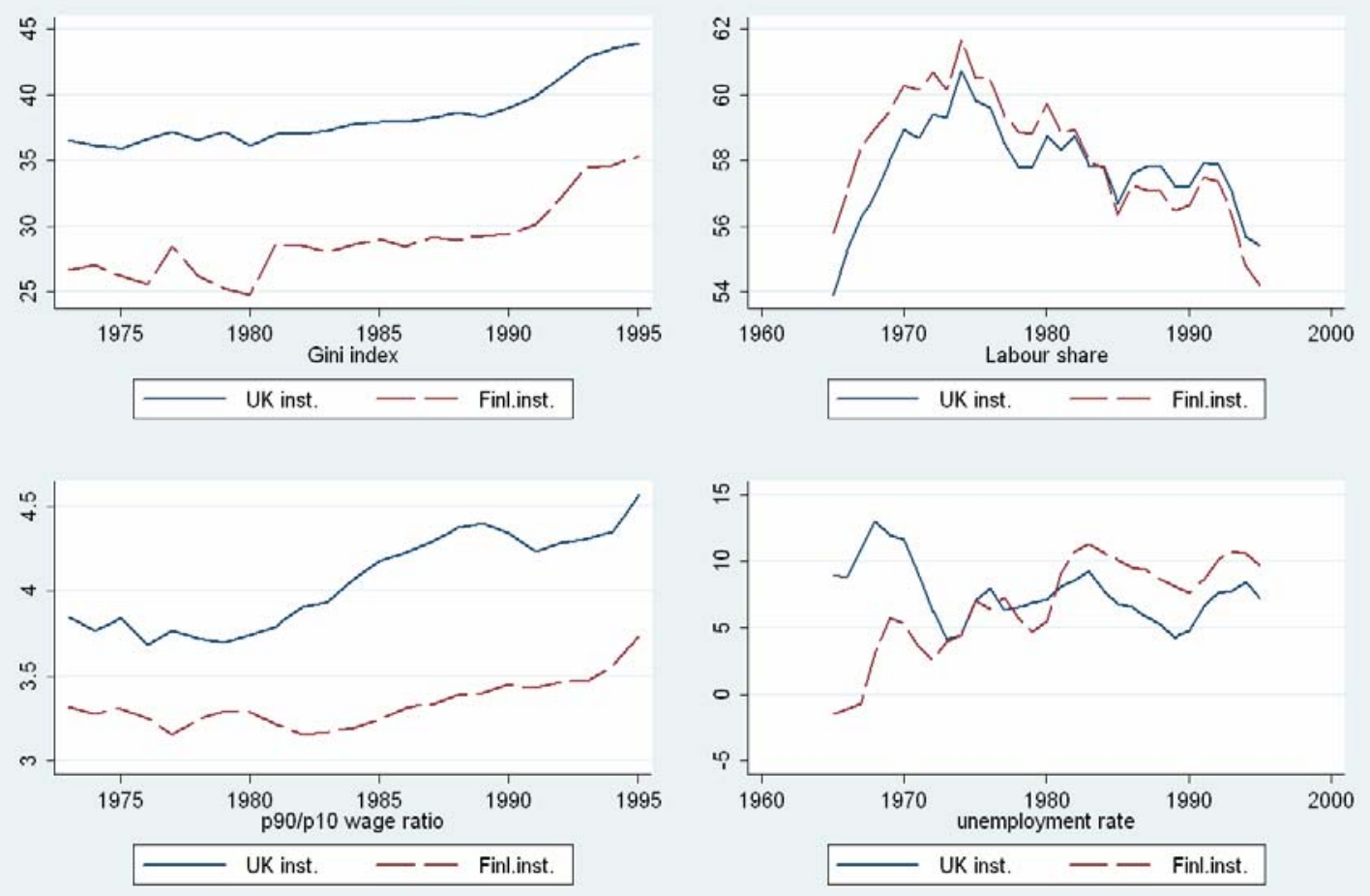
Table 1 - Determinants of labour share - OLS regressions

\begin{tabular}{|c|c|c|c|c|c|}
\hline & \multicolumn{3}{|c|}{ larger sample } & \multicolumn{2}{|c|}{ common sample } \\
\hline & 1 & 2 & 3 & 4 & 5 \\
\hline unemployment benefit & $\begin{array}{l}-3.226 \\
{[1.71]^{\star}}\end{array}$ & $\begin{array}{l}-2.492 \\
{[0.56]}\end{array}$ & $\begin{array}{c}1.98 \\
{[0.65]}\end{array}$ & $\begin{array}{l}-15.511 \\
{[3.63]^{\star \star \star}}\end{array}$ & $\begin{array}{l}-0.857 \\
{[0.18]}\end{array}$ \\
\hline bargaining coordination & $\begin{array}{c}0.981 \\
{[2.06]^{\star *}}\end{array}$ & $\begin{array}{c}3.178 \\
{[5.68]^{\star \star \star}}\end{array}$ & $\begin{array}{c}2.202 \\
{[3.66]^{\star \star \star}}\end{array}$ & $\begin{array}{c}3.299 \\
{[3.97]^{\star \star \star}}\end{array}$ & $\begin{array}{c}2.382 \\
{[2.41]^{\star *}}\end{array}$ \\
\hline union density rates & $\begin{array}{c}8.313 \\
{[4.60]^{\star \star \star}}\end{array}$ & $\begin{array}{l}4.477 \\
{[0.89]}\end{array}$ & $\begin{array}{l}-3.357 \\
{[0.96]}\end{array}$ & $\begin{array}{l}-7.358 \\
{[1.15]}\end{array}$ & $\begin{array}{l}-4.955 \\
{[0.95]}\end{array}$ \\
\hline ratio minimum/median wage & $\begin{array}{c}-4.012 \\
{[2.49]^{\star \star}}\end{array}$ & $\begin{array}{l}-6.092 \\
{[1.76]^{\star}}\end{array}$ & $\begin{array}{c}0.9 \\
{[0.24]}\end{array}$ & $\begin{array}{l}4.668 \\
{[0.89]}\end{array}$ & $\begin{array}{l}10.735 \\
{[1.79]^{\star}}\end{array}$ \\
\hline log capital per worker & $\begin{array}{c}-5.927 \\
{[4.43]^{\star \star *}}\end{array}$ & $\begin{array}{c}20.32 \\
{[5.94]^{\star \star \star}}\end{array}$ & $\begin{array}{c}21.477 \\
{[7.10]^{\star \star \star}}\end{array}$ & $\begin{array}{c}23.921 \\
{[6.04]^{\star \star \star}}\end{array}$ & $\begin{array}{c}26.679 \\
{[5.39]^{\star \star *}}\end{array}$ \\
\hline log oil price in national currency & $\begin{array}{l}-0.146 \\
{[0.87]}\end{array}$ & $\begin{array}{c}0.645 \\
{[3.36]^{\star \star \star}}\end{array}$ & $\begin{array}{c}-1.832 \\
{[3.21]^{\star \star \star}}\end{array}$ & $\begin{array}{l}0.395 \\
{[1.24]}\end{array}$ & $\begin{array}{l}-1.008 \\
{[0.83]}\end{array}$ \\
\hline average years of education & $\begin{array}{c}1.656 \\
{[5.50]^{\star \star \star}}\end{array}$ & $\begin{array}{c}-3.056 \\
{[2.67]^{\star \star \star}}\end{array}$ & $\begin{array}{c}-6.248 \\
{[4.98]^{\star \star \star}}\end{array}$ & $\begin{array}{c}-3.744 \\
{[2.60]^{\star \star}}\end{array}$ & $\begin{array}{c}-7.645 \\
{[4.50]^{\star \star \star}}\end{array}$ \\
\hline time trend & $\begin{array}{l}-0.083 \\
{[1.64]}\end{array}$ & $\begin{array}{c}-0.322 \\
{[2.26]^{\star \star}}\end{array}$ & $\begin{array}{c}0.03 \\
{[0.21]}\end{array}$ & $\begin{array}{c}-0.355 \\
{[2.56]^{\star \star}}\end{array}$ & $\begin{array}{l}0.026 \\
{[0.15]}\end{array}$ \\
\hline $\begin{array}{l}\text { Constant } \\
\text { Country fixed effects } \\
\text { Year fixed effects }\end{array}$ & yes & $\begin{array}{l}\text { yes } \\
\text { yes }\end{array}$ & $\begin{array}{l}\text { yes } \\
\text { yes } \\
\text { yes }\end{array}$ & $\begin{array}{l}\text { yes } \\
\text { yes }\end{array}$ & $\begin{array}{l}\text { yes } \\
\text { yes } \\
\text { yes }\end{array}$ \\
\hline Observations & $213 *$ & $213 *$ & $213 *$ & 130 & $130 \wedge$ \\
\hline $\mathrm{R}^{2}$ & 0.50 & 0.87 & 0.92 & 0.92 & 0.95 \\
\hline Number of countries & 14 & 14 & 14 & 11 & 11 \\
\hline
\end{tabular}

Robust standard errors - t-statistics in parentheses - * significant at 10\%; ** significant at 5\%; ** significant at $1 \%$

* Countries included: Australia (6), Belgium (4), Canada (24), Denmark (10), Finland (14), France (6), Germany (26), Italy (23), Netherlands (9), New Zealand (3), Norway (8), Sweden (21), United Kingdom (28), United States (31).

- Countries included: Canada (11), Denmark (10), Finland (10), France (6), Germany (10), Italy (10), Netherlands (9), Norway (7), Sweden (11), United Kingdom (23), United States (23). 
Table 2 - Determinants of p90/p10 decile ratio - OLS regressions

\begin{tabular}{l|ccc|cc} 
& \multicolumn{3}{|c|}{ larger sample } & \multicolumn{2}{c}{ common sample } \\
\hline & 1 & 2 & 3 & 4 & 5 \\
\hline unemployment benefit & -0.073 & 0.468 & 0.129 & 0.598 & 0.297 \\
& {$[0.31]$} & {$[0.96]$} & {$[0.24]$} & {$[1.20]$} & {$[0.55]$} \\
bargaining coordination & -0.573 & -0.172 & -0.127 & -0.189 & -0.149 \\
& {$[11.16]^{\star \star \star}$} & {$[2.73]^{\star \star \star}$} & {$[1.82]^{\star}$} & {$[3.05]^{\star \star \star}$} & {$[2.09]^{\star \star}$} \\
union density rates & -0.606 & -1.873 & -1.717 & -2.09 & -1.96 \\
& {$[3.70]^{\star \star \star}$} & {$[4.35]^{\star \star \star}$} & {$[4.00]^{\star \star \star}$} & {$[4.67]^{\star \star \star}$} & {$[4.38]^{\star \star \star}$} \\
ratio minimum/median wage & -0.773 & -4.342 & -3.739 & -4.3 & -3.713 \\
& {$[5.25]^{\star \star \star}$} & {$[5.87]^{\star \star \star}$} & {$[6.05]^{\star \star \star}$} & {$[5.58]^{\star \star \star}$} & {$[6.15]^{\star \star \star}$} \\
log capital per worker & -0.056 & -0.293 & 0.155 & -0.266 & 0.191 \\
& {$[0.46]$} & {$[0.74]$} & {$[0.33]$} & {$[0.66]$} & {$[0.40]$} \\
average years of education & 0.143 & -0.311 & -0.265 & -0.316 & -0.268 \\
time trend & {$[6.00]^{\star \star \star}$} & {$[1.92]^{\star}$} & {$[1.57]$} & {$[1.92]^{\star}$} & {$[1.59]$} \\
& -0.011 & 0.034 & 0.019 & 0.033 & 0.018 \\
Constant & {$[1.58]$} & {$[1.92]^{\star}$} & {$[0.99]$} & {$[1.86]^{\star}$} & {$[0.92]$} \\
Country fixed effects & yes & yes & yes & yes & yes \\
Year fixed effects & & yes & yes & yes & yes \\
Observations & & & yes & & yes \\
$\mathrm{R}^{2}$ & $137 *$ & $137 *$ & $137 *$ & $130 \star$ & $130 \star$ \\
Number of countries & 0.89 & 0.98 & 0.99 & 0.99 & 0.99 \\
& 14 & 14 & 14 & 11 & 11
\end{tabular}

Robust standard errors - t-statistics in parentheses - * significant at 10\%; ** significant at 5\%; ** significant at 1\%

- Countries included: Australia (4), Belgium (1), Canada (11), Denmark (10), Finland (10), France (6), Germany (10), Italy (10), Netherlands (9), New Zealand (2), Norway (7), Sweden (11), United Kingdom (23), United States (23).

A Countries included: Canada (11), Denmark (10), Finland (10), France (6), Germany (10), Italy (10), Netherlands (9), Norway (7), Sweden (11), United Kingdom (23), United States (23). 
Table 3 - Determinants of unemployment rate - OLS regressions

\begin{tabular}{l|ccc|cc} 
& \multicolumn{3}{|c|}{ larger sample } & \multicolumn{2}{c}{ common sample } \\
\hline & 1 & 2 & 3 & 4 & 5 \\
\hline unemployment benefit & 6.414 & 1.102 & -2.785 & 6.865 & -6.739 \\
& {$[4.18]^{\star \star \star}$} & {$[0.32]$} & {$[0.61]$} & {$[1.12]$} & {$[1.13]$} \\
bargaining coordination & -2.173 & -1.615 & -0.762 & -1.721 & 0.779 \\
& {$[5.17]^{\star \star \star}$} & {$[2.74]^{\star \star \star}$} & {$[1.27]$} & {$[1.88]^{\star}$} & {$[0.78]$} \\
union density rates & 6.015 & 12.241 & 9.805 & 28.099 & 27.281 \\
& {$[2.52]^{\star \star}$} & {$[2.47]^{\star \star}$} & {$[1.75]^{\star}$} & {$[3.31]^{\star \star \star}$} & {$[2.92]^{\star \star \star}$} \\
ratio minimum/median wage & -2.969 & 8.999 & 8.312 & 23.809 & 25.651 \\
& {$[3.08]^{\star \star \star}$} & {$[1.18]$} & {$[1.29]$} & {$[2.44]^{\star \star}$} & {$[2.32]^{\star \star}$} \\
tax wedge & 0.066 & -10.895 & -9.32 & -13.342 & -19.553 \\
& {$[0.03]$} & {$[2.50]^{\star \star}$} & {$[2.27]^{\star \star}$} & {$[1.71]^{\star}$} & {$[2.49]^{\star \star}$} \\
log capital per worker & -0.664 & -2.8 & -0.057 & 0.094 & 11.548 \\
& {$[1.00]$} & {$[1.00]$} & {$[0.02]$} & {$[0.02]$} & {$[2.38]^{\star \star}$} \\
exports plus imports as \% of GDP & 0.016 & 0.011 & -0.052 & 0.013 & -0.039 \\
& {$[1.10]$} & {$[0.36]$} & {$[1.33]$} & {$[0.39]$} & {$[0.81]$} \\
female labour force participation & -13.608 & -19.071 & -17.885 & -14.005 & -25.207 \\
time trend & {$[4.64]^{\star \star \star}$} & {$[1.66]^{\star}$} & {$[1.74]^{\star}$} & {$[0.96]$} & {$[1.87]^{\star}$} \\
& 0.261 & 0.467 & 0.4 & 0.461 & 0.225 \\
Constant & {$[6.35]^{\star \star \star}$} & {$[5.34]^{\star \star \star}$} & {$[3.26]^{\star \star \star}$} & {$[3.21]^{\star \star \star}$} & {$[1.45]$} \\
Country fixed effects & yes & yes & yes & yes & yes \\
Year fixed effects & & yes & yes & yes & yes \\
Observations & & & yes & & yes \\
$\mathrm{R}^{2}$ & & & $208 *$ & $130 \star$ & $130 \star$ \\
Number of countries & $208 *$ & $208 *$ & $208 *$ & 0.76 & 0.86 \\
& 0.74 & 0.80 & 0.86 & 0.711 & 11
\end{tabular}

Robust standard errors - t-statistics in parentheses - * significant at 10\%; ** significant at 5\%; *** significant at 1\%

* Countries included: Australia (4), Belgium (4), Canada (24), Denmark (10), Finland (14), France (6), Germany (24), Italy (23), Netherlands (9), New Zealand (2), Norway (8), Sweden (21), United Kingdom (28), United States (31).

^ Countries included: Canada (11), Denmark (10), Finland (10), France (6), Germany (10), Italy (10), Netherlands (9), Norway (7), Sweden (11), United Kingdom (23), United States (23). 
Table 4 - Determinants of personal income inequality - larger and common samples - OLS and IV estimates

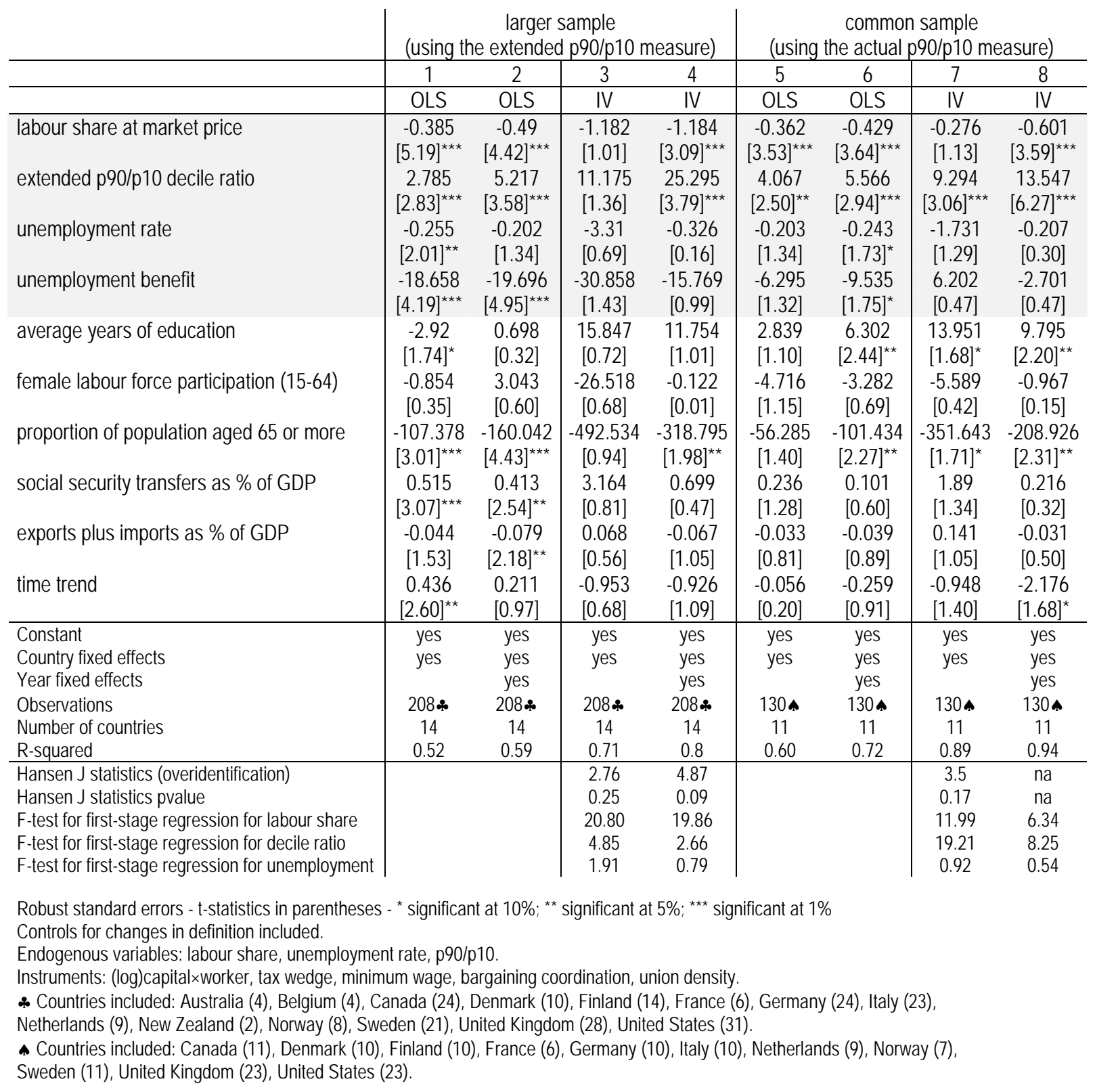


Table 5. - Determinants of personal income inequality - 3SLS regressions

\begin{tabular}{|c|c|c|c|c|}
\hline & & comm & sample & \\
\hline & $\begin{array}{c}1 \\
\text { gini1 }\end{array}$ & $\begin{array}{c}2 \\
\text { labour } \\
\text { share }\end{array}$ & $\begin{array}{c}3 \\
\text { decile } \\
\text { ratio }\end{array}$ & $\begin{array}{c}4 \\
\text { unempl. } \\
\text { rate }\end{array}$ \\
\hline $\begin{array}{l}\text { labour share at market price } \\
\text { p90/p10 decile ratio } \\
\text { unemployment rate }\end{array}$ & $\begin{array}{c}-0.97 \\
{[5.01]^{\star \star \star}} \\
15.024 \\
{[6.16]^{\star \star \star}} \\
1.802 \\
{[4.53]^{\star \star \star}}\end{array}$ & & & \\
\hline unemployment benefit & $\begin{array}{l}-6.815 \\
{[1.11]}\end{array}$ & $\begin{array}{l}-4.928 \\
{[1.07]}\end{array}$ & $\begin{array}{c}0.21 \\
{[0.56]}\end{array}$ & $\begin{array}{l}0.364 \\
{[0.06]}\end{array}$ \\
\hline union density rate & & $\begin{array}{l}-2.003 \\
{[0.45]}\end{array}$ & $\begin{array}{c}-2.036 \\
{[6.11]^{\star \star \star}}\end{array}$ & $\begin{array}{l}30.688 \\
{[5.60]^{\star \star \star}}\end{array}$ \\
\hline bargaining coordination & & $\begin{array}{c}2.285 \\
{[3.29]^{\star \star \star}}\end{array}$ & $\begin{array}{l}-0.137 \\
{[2.41]^{\star \star}}\end{array}$ & $\begin{array}{l}0.864 \\
{[1.01]}\end{array}$ \\
\hline ratio minimum/median wage & & $\begin{array}{l}-6.928 \\
{[1.25]}\end{array}$ & $\begin{array}{c}-3.659 \\
{[7.48]^{\star \star \star}}\end{array}$ & $\begin{array}{l}44.977 \\
{[6.61]^{\star \star \star}}\end{array}$ \\
\hline tax wedge & & & & $\begin{array}{l}-35.578 \\
{[5.75]^{\star \star \star}}\end{array}$ \\
\hline average years of education & & & $\begin{array}{c}-0.21 \\
{[1.67]^{\star}}\end{array}$ & \\
\hline log oil price in national currency & & $\begin{array}{c}-2.996 \\
{[3.25]^{\star \star \star}}\end{array}$ & & \\
\hline log capital per worker & & $\begin{array}{l}18.101 \\
{[4.84]^{\star \star \star}}\end{array}$ & $\begin{array}{l}0.191 \\
{[0.59]}\end{array}$ & $\begin{array}{l}14.141 \\
{[3.07]^{\star \star \star}}\end{array}$ \\
\hline female labour force participation (15-64) & $\begin{array}{l}7.038 \\
{[1.31]}\end{array}$ & & & \\
\hline proportion of population aged 65 or more & $\begin{array}{l}69.606 \\
{[1.15]}\end{array}$ & & & \\
\hline social security transfers as $\%$ of GDP & $\begin{array}{c}-1.467 \\
{[3.57]^{\star \star \star}}\end{array}$ & & & \\
\hline exports plus imports as $\%$ of GDP & $\begin{array}{c}-0.133 \\
{[3.11]^{\star \star *}}\end{array}$ & & & $\begin{array}{l}-0.029 \\
{[0.79]}\end{array}$ \\
\hline Constant & yes & yes & yes & yes \\
\hline Country fixed effects & yes & yes & yes & yes \\
\hline Year fixed effects & yes & yes & yes & yes \\
\hline Observations & $130 \%$ & $130 *$ & $130 *$ & $130 *$ \\
\hline Number of countries & 11 & 11 & 11 & 11 \\
\hline Root mean squared error & 2.16 & 1.1 & 0.08 & 1.31 \\
\hline $\mathrm{R}^{2}$ & 0.89 & 0.94 & 0.99 & 0.81 \\
\hline
\end{tabular}

Absolute value of z statistics in brackets - * significant at 10\%; ** significant at 5\%; ** significant at $1 \%$ Controls for changes in definition included.

* Countries included: Canada (11), Denmark (10), Finland (10), France (6), Germany (10), Italy (10), Netherlands (9), Norway (7), Sweden (11), United Kingdom (23), United States (23).

Table 6 - The effect of an increase of exogenous variables of 1 standard deviation

\begin{tabular}{l|cccc|} 
& gini1 & $\begin{array}{c}\text { labour } \\
\text { share }\end{array}$ & $\begin{array}{c}\text { decile } \\
\text { ratio }\end{array}$ & $\begin{array}{c}\text { unempl. } \\
\text { rate }\end{array}$ \\
\hline bargaining coordination & $-0.304^{*}$ & $0.382^{*}$ & -0.128 & 0.211 \\
union density rates & $0.866^{*}$ & -0.097 & $-0.554^{*}$ & $2.179^{\star}$ \\
ratio minimum/median wage & $1.327^{*}$ & -0.418 & $-1.240^{*}$ & $3.978^{*}$ \\
tax wedge & $-0.960^{\star}$ & & & $-1.165^{\star}$ \\
unemployment benefit & 0.037 & -0.153 & 0.037 & 0.017 \\
log capital per worker & $0.549^{*}$ & $1.373^{*}$ & 0.081 & $1.571^{*}$ \\
average years of education & $-0.599^{*}$ & & $-0.334^{*}$ & \\
exports plus imports as \% of GDP & $-0.630^{*}$ & & & -0.218 \\
log oil price in national currency & $0.934^{*}$ & $-1.437^{*}$ & &
\end{tabular}

Estimates used are those reported in table 5. The effect on the endogenous variables is measured as fraction of standard deviation of the latter.

* significant at least $10 \%$ 


\section{Appendix I: Wage and Employment Determination}

\section{The Bargaining Model}

The bargaining problem is given by

$$
\max _{w_{u}}\left(\frac{L}{\bar{L}}\left[\left((1-\tau) w_{u}\right)^{\rho}-(B)^{\rho}\right]\right)^{\gamma}\left(Y-w_{u} L-w_{s} H\right)^{1-\gamma}
$$

The resulting first-order condition is

$$
w_{u}^{\rho-1}\left[\rho(1-\tau)^{\rho}-\left((1-\tau)^{\rho}-\left(\frac{B}{w_{u}}\right)^{\rho}\right) \varepsilon_{L}\right]=\frac{1-\gamma}{\gamma} \frac{L\left((1-\tau)^{\rho} w_{u}^{\rho}-B^{\rho}\right)}{Y-H w_{s}-L w_{u}}
$$

Given the definition of the labour share, we can write (A.2) as

$$
\rho(1-\tau)^{\rho}=\left(\frac{1-\gamma}{\gamma}(1-\beta) \frac{\theta}{1-\theta}+\varepsilon_{L}\right)\left((1-\tau)^{\rho}-\left(\frac{B}{w_{u}}\right)^{\rho}\right)
$$

\section{Comparative Statics}

Consider first a number of comparative statics obtained from the production function. From equations (2), we obtain the elasticities of demand for the two types of labour

$$
\begin{aligned}
& \varepsilon_{L}=-\frac{\partial L}{\partial w_{u}} \frac{w_{u}}{L}=\frac{1}{1-(1-\beta)[\theta(1+\sigma)-\sigma]} \\
& \varepsilon_{H}=-\frac{\partial H}{\partial w_{s}} \frac{w_{s}}{H}=\frac{1}{1-\beta[\theta(1+\sigma)-\sigma]}
\end{aligned}
$$

From equations (1)-(4), (11), (12), (A.4) and (A.5) we have

$$
\operatorname{sign}\left[\frac{\partial \theta}{\partial x}\right]=\operatorname{sign}[\sigma]
$$




$$
\begin{aligned}
& \frac{\partial x}{\partial L}<0, \quad \frac{\partial x}{\partial H}<0, \quad \frac{\partial x}{\partial K}>0, \\
& \frac{\partial \omega}{\partial H}<0, \quad \frac{\partial \omega}{\partial L}>0, \quad \frac{\partial \omega}{\partial h}<0, \\
& \frac{\partial w_{u}}{\partial L}<0, \quad \frac{\partial w_{u}}{\partial H}>0, \quad \frac{\partial w_{u}}{\partial K}>0, \quad \frac{\partial w_{s}}{\partial L}>0, \quad \frac{\partial w_{s}}{\partial H}<0, \quad \frac{\partial w_{s}}{\partial K}>0, \\
& \frac{\partial \varepsilon_{L}}{\partial \theta}>0, \quad \frac{\partial \varepsilon_{H}}{\partial \theta}>0 .
\end{aligned}
$$

Using (11), we can shown

$$
\begin{aligned}
& \left.\frac{\partial H}{\partial L}\right|_{\bar{w}_{s}}=-\frac{\partial w_{s} / \partial L}{\partial w_{s} / \partial H}=\frac{H}{L}(1-\beta)[\theta(1+\sigma)-\sigma] \varepsilon_{H}>0 \\
& \left.\frac{\partial H}{\partial K}\right|_{\bar{w}_{s}}=-\frac{\partial w_{s} / \partial K}{\partial w_{s} / \partial H}=\frac{H}{K}(1+\sigma)(1-\theta) \varepsilon_{H}>0 \\
& \left.\frac{d h}{d L}\right|_{\bar{w}_{s}}=\frac{1}{L} \frac{\partial H}{\partial L}-\frac{H}{L_{2}}=-\frac{H}{L^{2}}(1+\sigma)(1-\theta) \varepsilon_{H}<0
\end{aligned}
$$

Write the equilibrium of the bargaining problem (A.3) as $\rho(1-\tau)^{\rho}=f\left(\theta, \varepsilon_{L}, \gamma\right) g\left(B, w_{u}\right)$, where

$$
\begin{aligned}
& f\left(\theta, \varepsilon_{L}, \gamma\right) \equiv \frac{1-\gamma}{\gamma}(1-\beta) \frac{\theta}{1-\theta}+\varepsilon_{L} \\
& g\left(B, w_{u}\right) \equiv(1-\tau)^{\rho}-\left(\frac{B}{w_{u}}\right)^{\rho}
\end{aligned}
$$

We define

$$
\begin{aligned}
& \Delta \equiv g\left[\frac{\partial f}{\partial \theta}+\frac{\partial f}{\partial \varepsilon_{L}} \frac{\partial \varepsilon_{L}}{\partial \theta}\right] \frac{\partial \theta}{\partial x}, \\
& \Delta_{1} \equiv \Delta\left[\frac{\partial x}{\partial L}+\frac{\partial x}{\partial H} \frac{d H}{d L}\right]+f \frac{\partial g}{\partial w_{u}} \frac{\partial w_{u}}{\partial L}, \\
& \Delta_{2} \equiv \Delta\left[\frac{\partial x}{\partial K}+\frac{\partial x}{\partial H} \frac{\partial H}{\partial K}\right]+f \frac{\partial g}{\partial w_{u}} \frac{\partial w_{u}}{\partial K}, \\
& \Delta_{3} \equiv\left[\Delta \frac{\partial x}{\partial H}+f \frac{\partial g}{\partial w_{u}} \frac{\partial w_{u}}{\partial H}\right] \frac{\partial H}{\partial \bar{w}_{s}} \frac{\partial \bar{w}_{s}}{\partial B} .
\end{aligned}
$$

These expressions can be used to derive the comparative static effects. In fact 


$$
\begin{aligned}
& \frac{d L}{d \gamma}=-g \frac{\partial f / \partial \gamma}{\Delta_{1}} \\
& \frac{d L}{d K}=-\frac{\Delta_{2}}{\Delta_{1}} \\
& \frac{d L}{d B}=-\frac{f \cdot \partial g / \partial B+\Delta_{3}}{\Delta_{1}}
\end{aligned}
$$

The impact of parameter changes may depend on the elasticity of substitution in production. Hence we need to consider three possible cases.

\section{Case 1: $\sigma>0$}

Using (A.6)-(A.9) and the fact that $\sigma>0$ implies $\partial \theta / \partial x>0$, we can establish: $\Delta<0, \Delta_{1}<0$, $\Delta_{2}>0$, while $\Delta_{3}$ may be positive or negative. Hence

$$
\frac{d L}{d \gamma}=-g \frac{\partial f / \partial \gamma}{\Delta_{1}}<0, \quad \frac{d L}{d K}=-\frac{\Delta_{2}}{\Delta_{1}}>0, \quad \frac{d L}{d B}=-\frac{f \cdot \partial g / \partial B+\Delta_{3}}{\Delta_{1}}
$$

From (A.6)-(A.9) we can now establish the effects of an increase in union bargaining power:

$$
\frac{d L}{d \gamma}<0, \quad \frac{d H}{d \gamma}<0, \quad \frac{d x}{d \gamma}>0, \quad \frac{d \theta}{d \gamma}>0, \quad \frac{d h}{d \gamma}>0, \quad \frac{d \omega}{d \gamma}<0
$$

An increase in the capital stock raises both skilled and unskilled employment, $d L / d K>0, d H / d K>0$. However, the impact of $K$ on $\omega$ and $\theta$ is ambiguous, as the increases in $H, L$ and $K$ have effects of opposite sign. However, we can obtain

$$
\begin{aligned}
& \frac{d h}{d K}=\frac{1}{L} \frac{d H}{d K}-\frac{H}{L^{2}} \frac{d L}{d K}=(1+\sigma)(1-\theta) \varepsilon_{H} \frac{H}{L K}\left[1-\frac{d L}{d K} \frac{K}{L}\right] \\
& \frac{d \theta}{d K}=\frac{\partial \theta}{\partial x}\left[\frac{\partial x}{\partial L} \frac{d L}{d K}+\frac{\partial x}{\partial H} \frac{d H}{d K}+\frac{\partial x}{\partial K}\right]=\frac{\partial \theta}{\partial x} \frac{x}{K}(1-\beta) \varepsilon_{H}\left[1-\frac{d L}{d K} \frac{K}{L}\right]
\end{aligned}
$$


If the elasticity of unskilled labour with respect to capital is less than one, then these two expressions are positive, implying $d \omega / d K<0$ and $d \theta / d K>0$.

The effects of an increase of $B$ are ambiguous. However, if $d L / d B<0$, it is then possible to show that

$$
\begin{aligned}
& \frac{d H}{d B}=\frac{\partial H}{\partial L} \frac{d L}{d B}+\frac{\partial H}{\partial w_{s}} \frac{\partial \bar{w}_{s}}{\partial B}<0 \\
& \frac{d \theta}{d B}=\frac{\partial \theta}{\partial x}\left[\frac{\partial x}{\partial L} \frac{d L}{d B}+\frac{\partial x}{\partial H} \frac{d H}{d B}\right]>0
\end{aligned}
$$

Case 2: $\sigma=0$

In this case $\partial \theta / \partial x=0$, hence $\Delta=0, \Delta_{1}<0, \Delta_{2}>0$, and $\Delta_{3}<0$. Then

$$
\frac{d L}{d \gamma}<0, \frac{d L}{d K}>0, \frac{d L}{d B}<0
$$

It is straightforward to show that the effects on $\omega$ are as in case 1 , while there is no impact on $\theta$.

\section{Case 3: $\sigma<0$}

In this case $\partial \theta / \partial x<0$, hence $\Delta>0, \Delta_{3}<0$, and $\Delta_{1}$ and $\Delta_{2}$ can be positive or negative. From the expressions in (A.12) to (A.14), it is clear that the comparative statics cannot be signed. 


\section{Appendix II: Data sources}

Data on income inequality are obtained from two alternative sources: the variable GINI1 is obtained from Brandolini 2003, whereas the variable GINI2 is from WIDER (June 2005). In both cases we have controlled for the type of income ("gross", "disposable" or "net") and the type of recipient ("household", "household equivalent" or "person equivalent"). As it can be seen by the figure A.11 below, the two indices provide very similar information for Italy, United Kingdom and United States, but not for other countries (especially for Nordic countries).

Data on labour shares are obtained from the OECD-Stan dataset, reconstructed backward to the 60's from the Research Group at the Bank of France, and made available to us by Emilie Daudey (see Daudey, 2005). They are defined as the ratio between "compensation per employees" and "gross domestic product (income approach)", at current prices, for the entire economy. In alternative specification we have restricted to the manufacturing sector, without significant differences (apart from the different mean values). Graphs of the variables are reported in figure A.12. The data can be corrected in order to include the self-employed (see Gollin, 2002). The most common adjusted measure of the labour share is obtained by assigning to the self-employed the average earnings of employees (also reported in figure A.12). Since we do not find this assumption very convincing, we stick to the unadjusted labour share.

Data on unemployment rates are from Nickell and Nunziata 2001, whereas the replacement rate of the unemployment subsidy is obtained on a biannual base by OECD 2002 (and then replicated for the missing years). The wage differential is computed as the ratio between the $9^{\text {th }}$ and $1^{\text {st }}$ earnings decile, on data on earnings distribution from OECD (Trends in earning dispersion database). The Kaitz index (minimum to median wage) is obtained from OECD (Minimum wage database). For countries were minimum wages are non-existent this variable has been set equal to unity (Denmark, Finland, Germany, Italy, Norway, Sweden and UK for most of the sample 
period). Data on union density (ratio between union membership and active dependent employment) have been kindly provided by Jelle Visser (University of Amsterdam). Lastly, the tax wedge measure is obtained from Nickell and Nunziata 2001.

The capital stock is derived from the Penn World Tables, Mark 5.6 (see Summer and Heston 1991). Since data on labour force composition by skills are not available over a long time span, we relied on a proxy derived from educational attainment, i.e. measures of human capital, the average years of education in the adult population, from Cohen and Soto (2007). The oil price in national currency is computed from the IMF Financial Statistics. Female participation, age composition and social transfer are obtained from Comparative Welfare States Data Set, assembled by Evelyne Huber, Charles Ragin, and John D. Stephens (December 1997) and updated by David Brady, Jason Beckfield, and John Stephens (April 2004), downloaded from www.lisproject.org on 20/01/2008. 


\section{Appendix III - Additional tables and figures}

Table A.1 - Descriptive statistics for main variables - sample means by countries - larger sample

\begin{tabular}{l|cccccc} 
country & GINI1 & GINI2 & LS1 & P90/P10 & UR & BEN \\
\hline Australia & 32.83 & 38.42 & 50.99 & 2.84 & 5.45 & 0.21 \\
Belgium & 27.75 & 26.29 & 55.29 & 2.40 & 11.68 & 0.43 \\
Canada & 36.03 & 31.20 & 54.11 & 4.24 & 8.55 & 0.28 \\
Denmark & 32.86 & 32.07 & 55.48 & 2.18 & 7.19 & 0.53 \\
Finland & 21.76 & 28.67 & 54.25 & 2.44 & 6.52 & 0.30 \\
France & 38.33 & 39.19 & 53.26 & 3.31 & 7.30 & 0.30 \\
Germany & 36.22 & 31.58 & 54.82 & 2.84 & 3.80 & 0.29 \\
Italy & 34.71 & 34.67 & 48.11 & 2.33 & 6.52 & 0.03 \\
Japan & na & 34.86 & 49.73 & 3.07 & 1.75 & 0.11 \\
Korea & na & 34.18 & 41.25 & 3.97 & na & na \\
Netherlands & 28.55 & 28.55 & 54.44 & 2.51 & 10.14 & 0.51 \\
New Zealand & 27.23 & 36.56 & 49.29 & 2.94 & 5.17 & 0.31 \\
Norway & 22.64 & 32.60 & 48.14 & 2.09 & 4.33 & 0.39 \\
Sweden & 47.12 & 31.40 & 58.93 & 2.06 & 1.70 & 0.14 \\
United Kingdom & 27.52 & 25.98 & 58.13 & 3.25 & 6.43 & 0.23 \\
United States & 37.58 & 35.49 & 57.58 & 4.08 & 6.02 & 0.12 \\
\hline Total & 33.98 & 31.69 & 54.98 & 3.02 & 5.92 & 0.23
\end{tabular}

Legend: Variables as in table A.3.

Table A.2 - Sample sizes for main variables - larger sample

\begin{tabular}{l|cccccc} 
CounTRY & GINI & GINI2 & LS1 & P90/P10 & UR & BEN \\
\hline Australia & 6 & 13 & 44 & 25 & 36 & 40 \\
Belgium & 4 & 6 & 44 & 8 & 41 & 40 \\
Canada & 24 & 28 & 43 & 12 & 36 & 40 \\
Denmark & 10 & 4 & 34 & 11 & 39 & 40 \\
Finland & 14 & 14 & 44 & 21 & 41 & 40 \\
France & 6 & 6 & 41 & 39 & 41 & 40 \\
Germany & 28 & 10 & 44 & 15 & 41 & 40 \\
Italy & 23 & 18 & 44 & 11 & 41 & 40 \\
Japan & na & 26 & 44 & 25 & 41 & 40 \\
Korea & na & 21 & 34 & 16 & na & na \\
Netherlands & 9 & 17 & 35 & 23 & 41 & 40 \\
New Zealand & 3 & 18 & 34 & 14 & 36 & 40 \\
Norway & 10 & 13 & 34 & 12 & 36 & 40 \\
Sweden & 26 & 16 & 44 & 24 & 41 & 40 \\
United Kingdom & 36 & 31 & 44 & 31 & 41 & 40 \\
United States & 37 & 32 & 44 & 28 & 41 & 40 \\
\hline Total & 236 & 273 & 651 & 315 & 593 & 600
\end{tabular}

Legend: Variables as in table A.3. 
Table A.3 - Descriptive statistics for variables in the dataset - sample means - larger sample

\begin{tabular}{l|ccccc} 
Variable & Obs & Mean & Std. Dev. & Min & Max \\
\hline GINI1 & 236 & 33.981 & 7.295 & 19.900 & 54.300 \\
P90/P10 & 142 & 3.024 & 0.774 & 1.953 & 4.630 \\
LS1 & 236 & 54.980 & 4.136 & 42.558 & 64.909 \\
UR & 236 & 5.916 & 3.194 & 0.400 & 16.800 \\
BEN & 233 & 0.235 & 0.138 & 0.003 & 0.562 \\
COW & 234 & 1.936 & 0.718 & 1 & 3 \\
UDNET & 236 & 0.445 & 0.182 & 0.102 & 0.837 \\
MINIM & 236 & 0.804 & 0.258 & 0.327 & 1.000 \\
TW & 233 & 0.508 & 0.102 & 0.297 & 0.783 \\
FEMALE & 234 & 0.531 & 0.111 & 0.159 & 0.759 \\
OVER65 & 236 & 0.166 & 0.023 & 0.112 & 0.211 \\
EDU & 236 & 10.055 & 1.476 & 6.179 & 12.475 \\
KPW & 214 & 10.226 & 0.341 & 9.076 & 10.826 \\
OIL & 236 & 3.912 & 2.516 & -0.291 & 10.864 \\
OPENC & 232 & 49.885 & 23.247 & 9.259 & 146.449 \\
WELFARE & 236 & 13.623 & 4.520 & 5.000 & 28.909
\end{tabular}

Legend:

GINI1 = Gini index on personal income distribution, from Brandolini 2003

GINI2 = Gini index on personal income distribution, from WIDER

$\mathrm{P} 90 / \mathrm{P} 10=$ ratio between $90^{\text {th }}$ and $10^{\text {th }}$ percentile in earnings distribution, from OECD

LS1 = labour share on value added at market price, from OECD-Stan database

UR = unemployment rate, from Nickell-Nunziata 2001

BEN = unemployment benefit, from OECD 2001

COW = bargaining coordination (1-3), from Nickell-Nunziata 2001

UDNET = union density, from Nickell-Nunziata 2001

MINIM = ratio of minimum wage to median wage, from OECD

$\mathrm{TW}=$ tax wedge, from Nickell-Nunziata 2001

FEMALE $=$ female participation rate, from OECD Labour force statistics

OVER65 = Proportion of population over 15 that is over 65 years of age, from Comparative welfare states data set

EDU = average years of schooling of population 25 and over, whether studying or not, from Cohen and Soto (2007)

KPW $=(\log$ of $)$ capital per worker, from Summer and Heston 1991, updated with mark 5.6 of the Penn tables

OIL $=(\log$ of $)$ oil price in national currency, from IMF Financial Statistics

OPENC $=$ export+import/gdp at current prices, from OECD database

WELFARE $=$ Total social security transfers as $\%$ of GDP, from Comparative welfare states data set (www.lisproject.org) 
Table A.4 - Pairwise correlation matrix - larger sample

\begin{tabular}{|c|c|c|c|c|c|c|c|c|c|c|c|c|c|c|c|}
\hline & GINI1 & P90/P10 & LS1 & UR & BEN & cow & UDNET & MINIM & TW & FEMALE & OVER65 & EDU & KPW & OIL & OPENC \\
\hline LS1 & $0.1509^{*}$ & -0.0584 & 1.0000 & & & & & & & & & & & & \\
\hline BEN & $-0.4705^{\star}$ & $-0.4325^{\star}$ & $0.1244^{*}$ & $0.3204^{*}$ & 1.0000 & & & & & & & & & & \\
\hline cow & 0.0951 & $-0.6810^{*}$ & -0.0471 & $-0.4050^{*}$ & $0.1966^{\star}$ & 1.0000 & & & & & & & & & \\
\hline UDNET & -0.1112 & $-0.6823^{\star}$ & $0.2038^{*}$ & -0.0050 & $0.2213^{\star}$ & $0.3754^{*}$ & 1.0000 & & & & & & & & \\
\hline MINIM & $-0.1605^{\star}$ & $-0.5864^{\star}$ & $-0.1191^{*}$ & $-0.1770^{*}$ & -0.0623 & $0.3265^{\star}$ & $0.5936^{*}$ & 1 & & & & & & & \\
\hline OVER65 & -0.1133 & $-0.4717^{\star}$ & $0.2098^{*}$ & $0.3289^{*}$ & $0.2665^{*}$ & $0.1762^{\star}$ & $0.4115^{\star}$ & $0.2920^{*}$ & $0.5999 *$ & $0.3112^{*}$ & 1 & & & & \\
\hline EDU & -0.0664 & 0.0567 & $0.3390^{*}$ & $0.3646^{*}$ & $0.2232^{\star}$ & $-0.1166^{*}$ & 0.0204 & $-0.3134^{*}$ & -0.0103 & $0.5469 *$ & $0.3348^{*}$ & 1 & & & \\
\hline KPW & -0.0517 & $-0.2881^{*}$ & $0.3319^{*}$ & $0.4403^{*}$ & $0.2425^{*}$ & 0.0781 & 0.0661 & $-0.2062^{\star}$ & $0.3469 *$ & $0.3123^{*}$ & $0.4624^{*}$ & $0.6464^{*}$ & 1 & & \\
\hline OIL & -0.0219 & $-0.1987^{*}$ & $-0.4320^{*}$ & $0.2258^{\star}$ & $-0.1126^{\star}$ & $0.1945^{\star}$ & 0.0430 & 0.0462 & $0.2297^{*}$ & -0.0231 & $0.1550^{*}$ & $-0.1956^{*}$ & -0.0065 & 1 & \\
\hline OPENC & $-0.3297^{*}$ & $-0.5588^{\star}$ & -0.0090 & $0.2564^{*}$ & $0.6227^{\star}$ & $0.3448^{\star}$ & $0.3652^{\star}$ & 0.0634 & $0.2416^{*}$ & -0.0431 & $0.3681^{*}$ & 0.0659 & $0.2876^{*}$ & 0.0719 & 1 \\
\hline WELFARE & $-0.2068^{\star}$ & $-0.4930^{*}$ & $0.1351^{*}$ & $0.5305^{\star}$ & $0.5695 *$ & $0.1828^{*}$ & $0.1757^{\star}$ & 0.0569 & $0.5968^{*}$ & $0.0810^{*}$ & $0.5918^{*}$ & $0.2398^{*}$ & $0.4324^{*}$ & $0.1086^{*}$ & $0.5248^{\prime}$ \\
\hline
\end{tabular}

Legend: Variables as in table A.3 - * indicates statistical significance above 95\%

Figure A.5 - Predictive ability of the model estimated in table 5 - Labour share

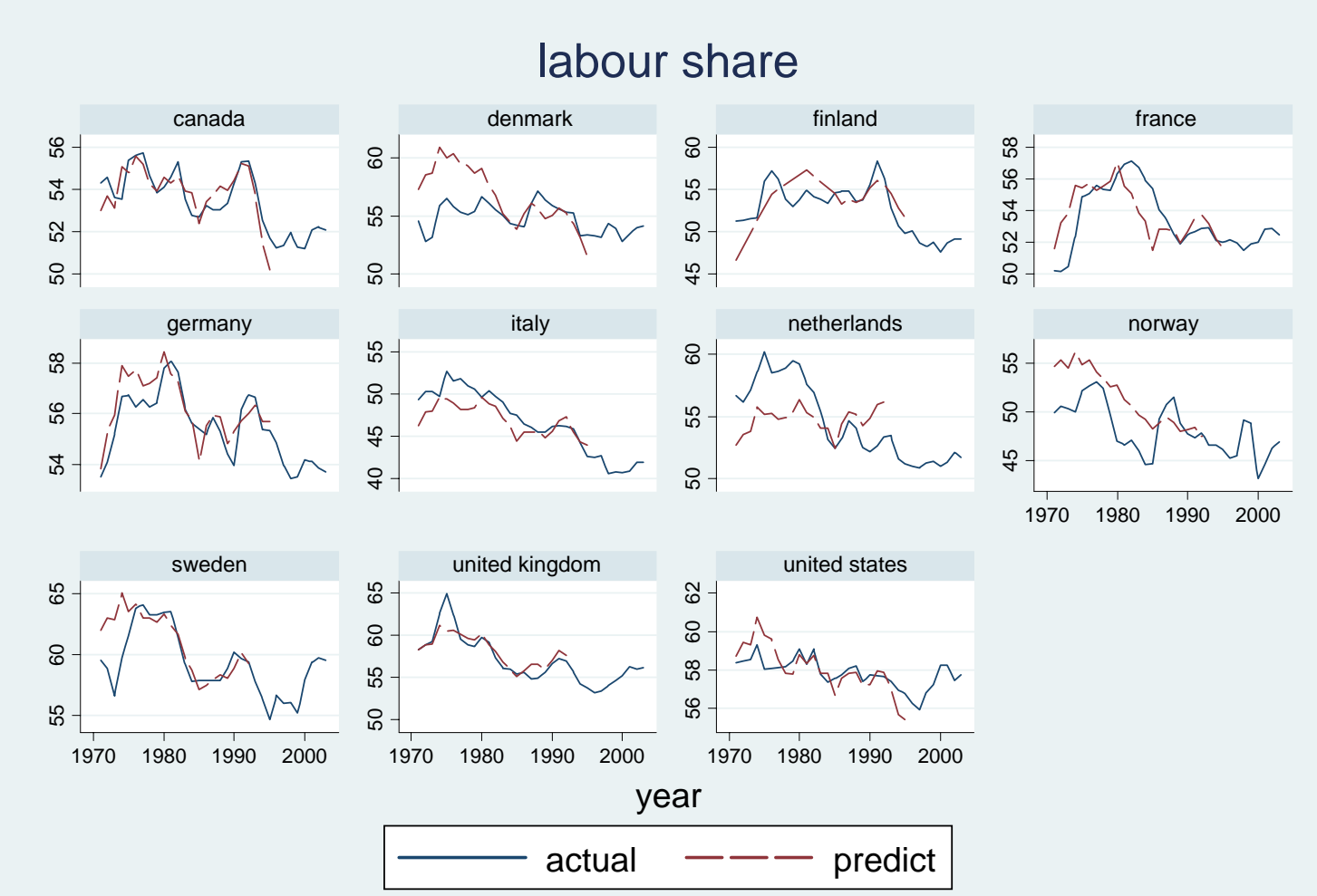


Figure A.6 - Predictive ability of the model estimated in table 5 - P90/P10 wage decile ratio

\section{wage differential p90/p10}

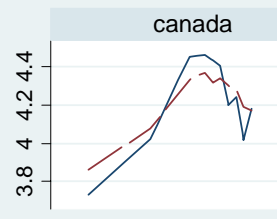

germany

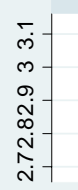

1

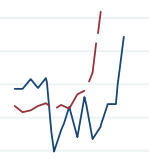

sweden

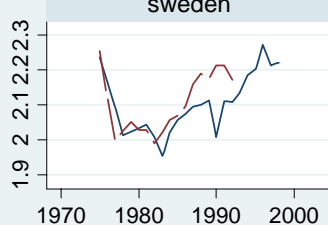

denmark

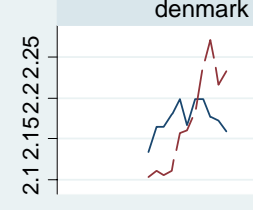

italy

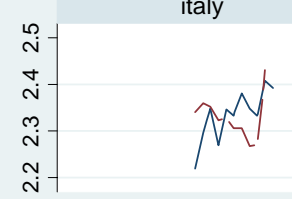

united kingdom

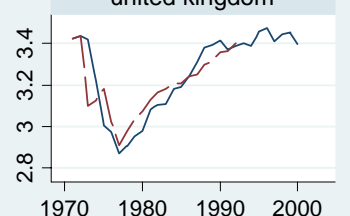

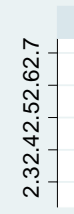

finland

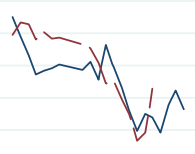

netherlands

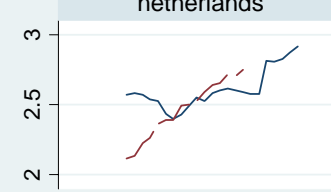

united states

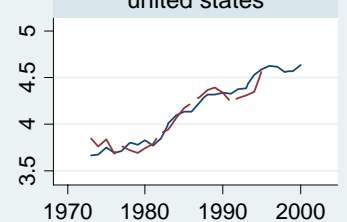

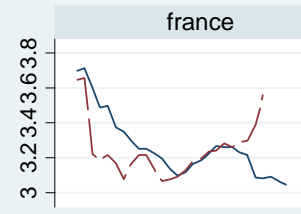

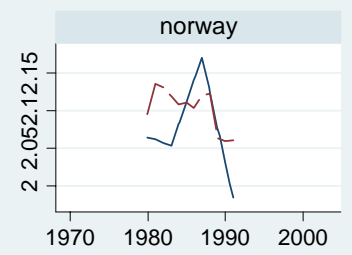

year

actual $-\longrightarrow$ predict

Figure A.7 - Predictive ability of the model estimated in table 5 - unemployment rate

\section{unemployment rate}
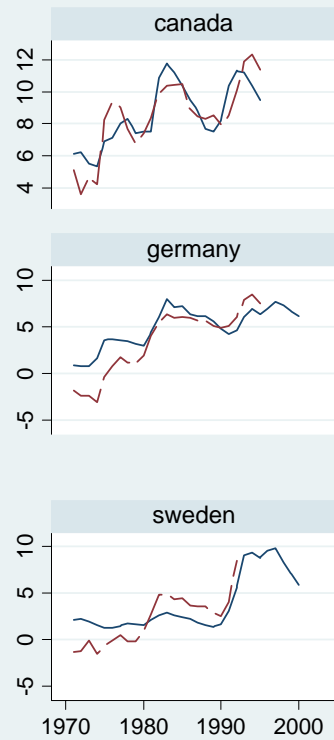
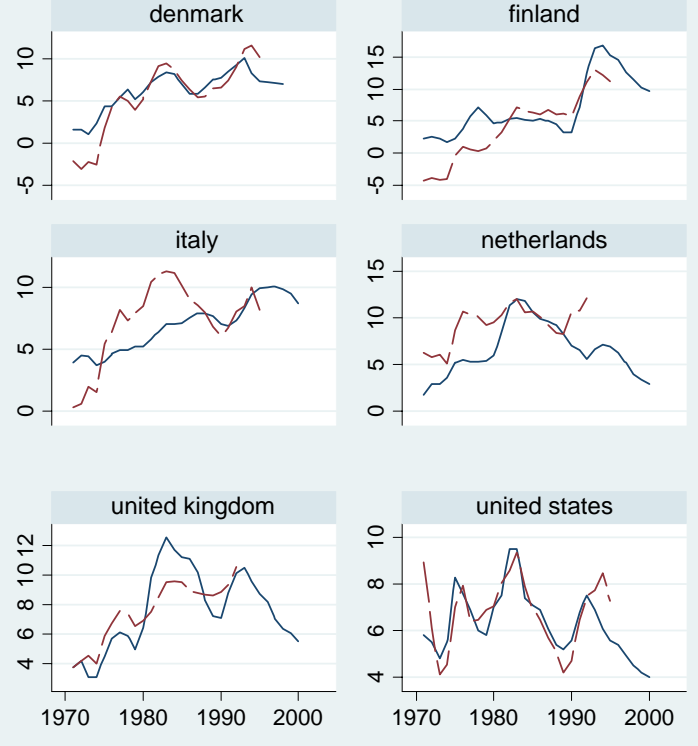
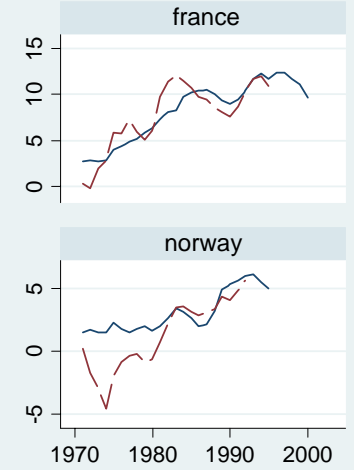

year

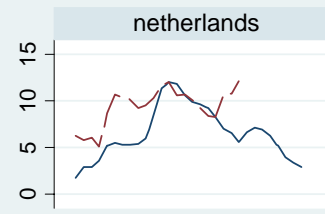

$1970 \quad 1980 \quad 1990 \quad 2000$ predict 
Table A.8 - Dickey-Fuller Stationarity test for inequality measures

\begin{tabular}{|c|c|c|c|c|}
\hline COUNTRY & GINI1 (obs) & $\Delta \mathrm{GINI}$ (obs) & GINI2 (obs) & $\Delta \mathrm{GINI} 2$ (obs) \\
\hline Australia & na & na & na & na \\
\hline Belgium & $0.346(3)$ & na & $0.433(3)$ & na \\
\hline Canada & $-2.893^{\star *}(23)$ & $-7.211^{\star \star \star}(22)$ & $-1.514(26)$ & $-5.830 * \star \star(25)$ \\
\hline Denmark & $-4.105^{\star \star \star}(9)$ & $-1.194(8)$ & na & na \\
\hline Finland & $-2.687^{*}(9)$ & $-4.437^{\star \star \star}(8)$ & $1.531(10)$ & $-1.343(9)$ \\
\hline France & na & na & na & na \\
\hline Germany & $-1.719(25)$ & $-3.972^{\star \star \star}(24)$ & $-1.209(6)$ & $-0.533(5)$ \\
\hline Italy & $-4.368 * \star \star(22)$ & $-3.852^{\star \star \star}(21)$ & $-2.977^{\star \star}(17)$ & $-3.956^{\star \star \star}(16)$ \\
\hline Japan & na & na & na & na \\
\hline Korea & na & na & na & na \\
\hline Netherlands & $-0.109(8)$ & $-2.394(7)$ & $-0.952(16)$ & $-3.187^{\star *}(15)$ \\
\hline New Zealand & na & na & na & na \\
\hline Norway & $-0.858(9)$ & $-4.053^{\star \star \star}(9)$ & $-1.083(8)$ & $0.183(6)$ \\
\hline Sweden & $-1.654(25)$ & $-1.357(23)$ & $-6.694^{\star \star \star}(13)$ & $-4.130 * \star \star(11)$ \\
\hline United Kingdom & $0.191(35)$ & $-5.960 * \star \star ~(34)$ & $0.819(30)$ & $-5.239 * \star \star(29)$ \\
\hline United States & $0.651(36)$ & $-5.409 * \star *(34)$ & $0.290(31)$ & $-4.736^{\star \star \star}(29)$ \\
\hline
\end{tabular}

$*$ stationary at $10 \% ; * *$ stationary at $5 \% ; * * *$ stationary at $1 \%$

Table A.9 - Determinants of personal income inequality - larger and common samples - OLS first differences

\begin{tabular}{l|cc|cc} 
& \multicolumn{2}{|c|}{ larger sample } & \multicolumn{2}{c}{ common sample } \\
\hline$\Delta$ labour share at market price & 1 & 2 & 3 & 4 \\
\hline extended p90/p10 decile ratio & -0.157 & -0.072 & -0.138 & -0.087 \\
& {$[2.38]^{\star \star}$} & {$[0.85]$} & {$[1.85]^{\star}$} & {$[0.89]$} \\
$\Delta$ unemployment rate & 0.46 & 0.791 & 0.834 & 1.431 \\
& {$[1.16]$} & {$[1.46]$} & {$[1.76]^{\star}$} & {$[1.67]^{\star}$} \\
$\Delta$ unemployment benefit & 0.02 & 0.1 & 0.031 & 0.139 \\
& {$[0.16]$} & {$[0.71]$} & {$[0.22]$} & {$[0.80]$} \\
$\Delta$ average years of education & -0.772 & -0.379 & -2.169 & -2.277 \\
& {$[0.15]$} & {$[0.13]$} & {$[0.43]$} & {$[0.66]$} \\
$\Delta$ female labour force participation (15-64) & -3.289 & 2.22 & -0.453 & 3.806 \\
& {$[1.09]$} & {$[0.63]$} & {$[0.12]$} & {$[0.99]$} \\
$\Delta$ proportion of population aged 65 or more & -1.6 & -0.953 & -1.321 & -0.273 \\
& {$[2.55]^{\star \star}$} & {$[0.71]$} & {$[1.43]$} & {$[0.30]$} \\
$\Delta$ social security transfers as \% of GDP & 13.594 & -20.91 & 35.116 & -60.168 \\
& {$[0.30]$} & {$[0.40]$} & {$[0.65]$} & {$[0.75]$} \\
$\Delta$ exports plus imports as \% of GDP & -0.03 & -0.023 & -0.044 & -0.239 \\
& {$[0.15]$} & {$[0.12]$} & {$[0.21]$} & {$[1.06]$} \\
& -0.038 & -0.03 & -0.02 & -0.022 \\
Constant & {$[2.27]^{\star \star}$} & {$[1.73]^{\star}$} & {$[1.33]$} & {$[1.20]$} \\
Year fixed effects & yes & yes & yes & yes \\
Observations & & yes & & yes \\
Number of countries & $181 *$ & $181 *$ & $120 \star$ & $120 \star$ \\
$\mathrm{R}^{2}$ & 11 & 11 & 10 & 10 \\
& 0.08 & 0.28 & 0.09 & 0.33
\end{tabular}

Robust standard errors - t-statistics in parentheses - * significant at 10\%; ** significant at 5\%; *** significant at $1 \%$ Controls for changes in definition included.

* Countries included: Belgium (3), Canada (23), Denmark (9), Finland (9), Germany (23), Italy (22), Netherlands (8), Norway (7), Sweden (20), United Kingdom (27), United States (30).

^ Countries included: Canada (11), Denmark (9), Finland (9), Germany (10), Italy (10), Netherlands (8), Norway (6), Sweden (11), United Kingdom (23), United States (23). 
Table A.10 - Determinants of personal income inequality - 3SLS regressions - Gini index from WIDER

\begin{tabular}{|c|c|c|c|c|}
\hline & \multicolumn{4}{|c|}{ common sample } \\
\hline & $\begin{array}{c}1 \\
\text { gini2 }\end{array}$ & $\begin{array}{c}2 \\
\text { labour } \\
\text { share }\end{array}$ & $\begin{array}{c}3 \\
\text { decile } \\
\text { ratio }\end{array}$ & $\begin{array}{c}4 \\
\text { unempl. } \\
\text { rate }\end{array}$ \\
\hline labour share at market price & $\begin{array}{c}-0.755 \\
{[2.38]^{\star \star}}\end{array}$ & & & \\
\hline p90/p10 decile ratio & $\begin{array}{c}8.954 \\
{[2.58]^{\star \star \star}}\end{array}$ & & & \\
\hline unemployment rate & $\begin{array}{c}1.168 \\
{[2.82]^{\star \star \star}}\end{array}$ & & & \\
\hline unemployment benefit & $\begin{array}{c}-13.647 \\
{[1.78]^{\star}}\end{array}$ & $\begin{array}{c}5.67 \\
{[0.98]}\end{array}$ & $\begin{array}{c}-1.364 \\
{[2.64]^{\star \star \star}}\end{array}$ & $\begin{array}{c}9.908 \\
{[1.79]^{*}}\end{array}$ \\
\hline union density rate & & $\begin{array}{l}-7.704 \\
{[1.32]}\end{array}$ & $\begin{array}{l}-0.528 \\
{[1.02]}\end{array}$ & $\begin{array}{l}-4.854 \\
{[0.87]}\end{array}$ \\
\hline bargaining coordination & & $\begin{array}{l}0.741 \\
{[1.43]}\end{array}$ & $\begin{array}{l}-0.036 \\
{[0.73]}\end{array}$ & $\begin{array}{l}-1.077 \\
{[2.17]^{\star \star}}\end{array}$ \\
\hline ratio minimum/median wage & & $\begin{array}{l}0.093 \\
{[0.04]}\end{array}$ & $\begin{array}{l}-0.536 \\
{[2.24]^{\star \star}}\end{array}$ & $\begin{array}{l}0.885 \\
{[0.37]}\end{array}$ \\
\hline tax wedge & & & & $\begin{array}{l}-3.008 \\
{[0.55]}\end{array}$ \\
\hline average years of education & & & $\begin{array}{l}-0.078 \\
{[0.44]}\end{array}$ & \\
\hline log oil price in national currency & & $\begin{array}{c}2.514 \\
{[2.79]^{\star \star \star}}\end{array}$ & & \\
\hline log capital per worker & & $\begin{array}{l}12.455 \\
{[5.51]^{\star \star \star}}\end{array}$ & $\begin{array}{l}-0.362 \\
{[1.94]^{\star}}\end{array}$ & $\begin{array}{l}-1.984 \\
{[0.89]}\end{array}$ \\
\hline female labour force participation (15-64) & $\begin{array}{l}-0.186 \\
{[0.04]}\end{array}$ & & & \\
\hline proportion of population aged 65 or more & $\begin{array}{c}79.31 \\
{[1.76]^{\star}}\end{array}$ & & & \\
\hline social security transfers as $\%$ of GDP & $\begin{array}{l}-0.33 \\
{[1.16]}\end{array}$ & & & \\
\hline exports plus imports as $\%$ of GDP & $\begin{array}{l}-0.033 \\
{[0.58]}\end{array}$ & & & $\begin{array}{c}-0.071 \\
{[2.51]^{\star \star}}\end{array}$ \\
\hline Constant & yes & yes & yes & yes \\
\hline Country fixed effects & yes & yes & yes & yes \\
\hline Year fixed effects & yes & yes & yes & yes \\
\hline Observations & $126 *$ & 126 & $126 *$ & $126 *$ \\
\hline Number of countries & 13 & 13 & 13 & 13 \\
\hline Root mean squared error & 1.91 & 1.2 & 0.1 & 1.11 \\
\hline $\mathrm{R}^{2}$ & 0.83 & 0.92 & 0.98 & 0.86 \\
\hline
\end{tabular}

Absolute value of $z$ statistics in brackets - * significant at $10 \%$; ** significant at $5 \%$; ** significant at $1 \%$ Controls for changes in definition included.

* Countries included: Australia (7), Belgium (4), Canada (9), Finland (4), France (5), Italy (6), Japan (13), Netherlands (15), New Zealand (3), Norway (4), Sweden (15), United Kingdom (22), United States (19). 
Figure A.11 - Gini indices of income inequality

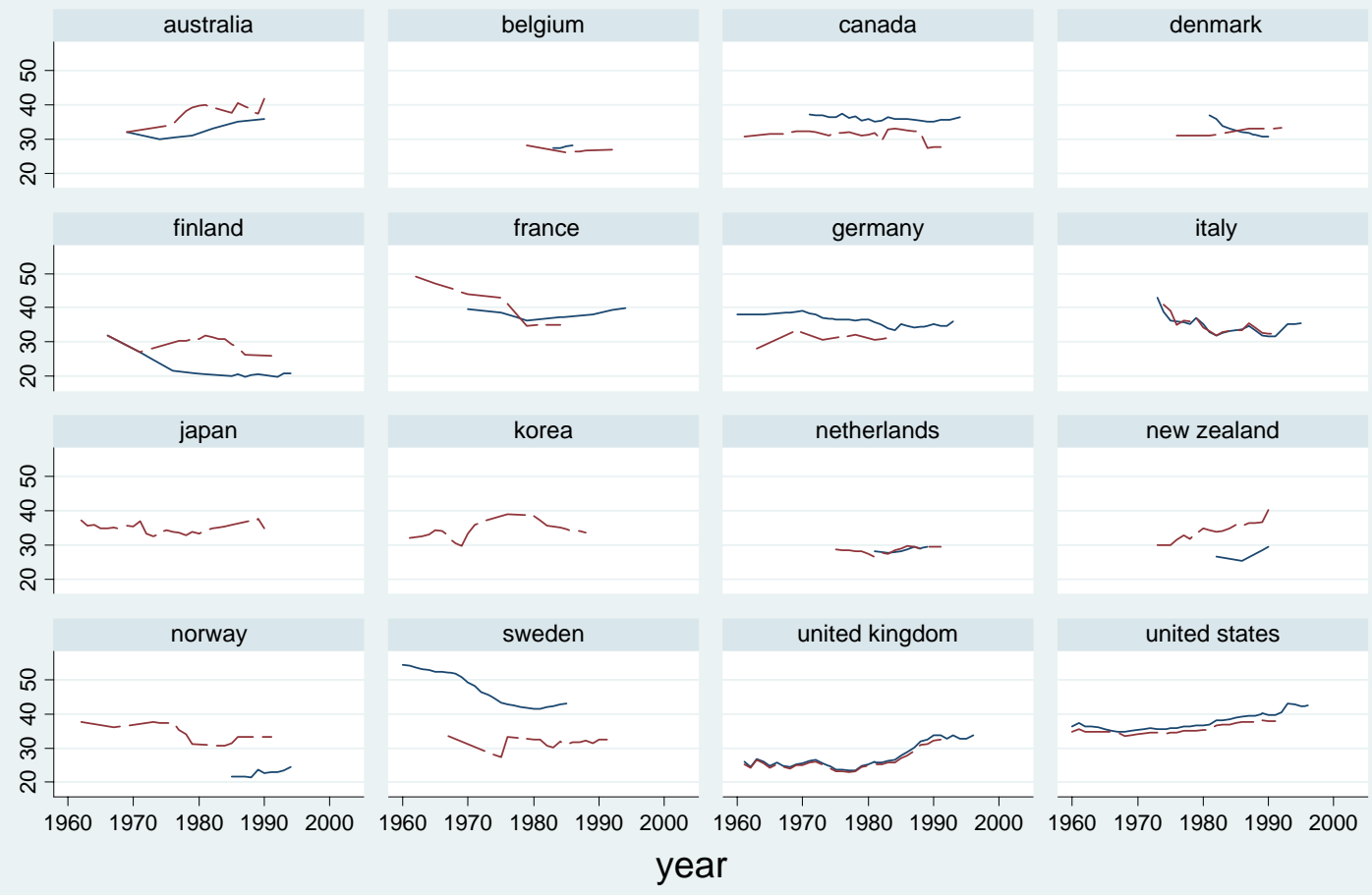

Brandolini $2003 \quad--$ Wider

Figure A.12 - Labour shares
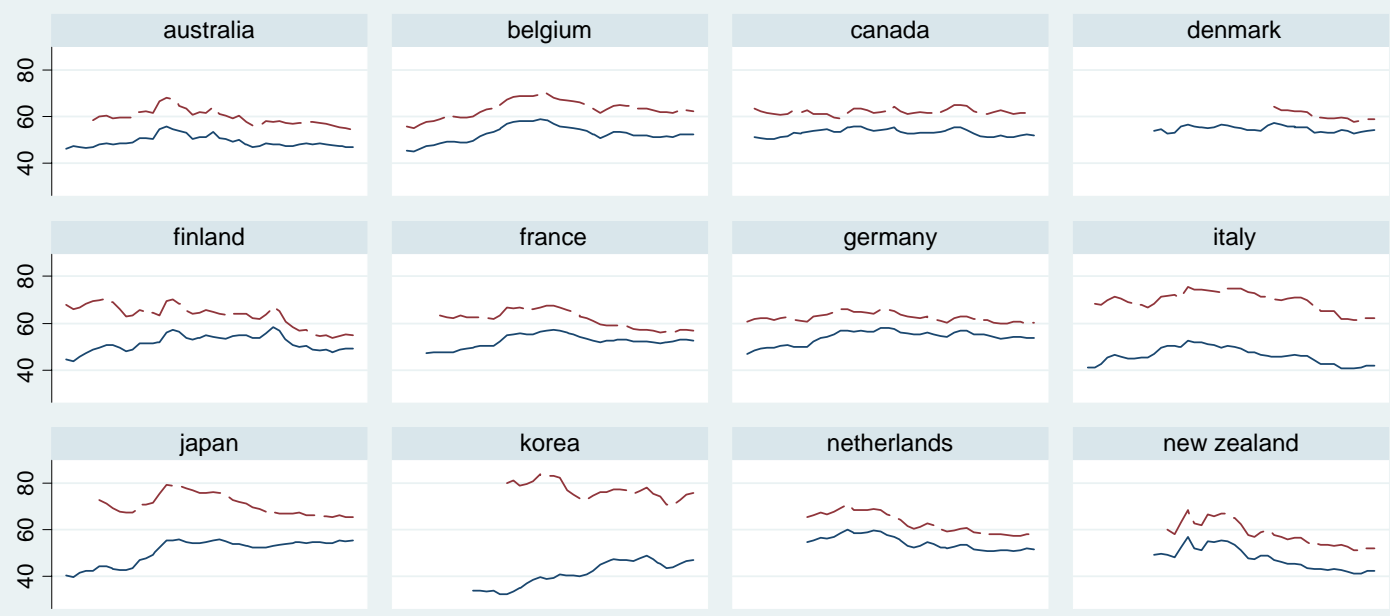

new zealand
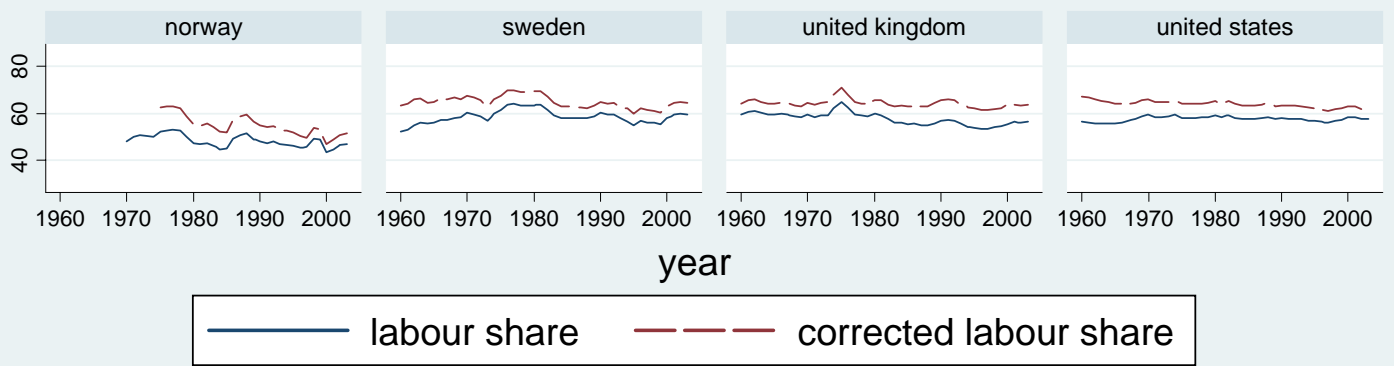